\title{
Fault zone architecture within Miocene-Pliocene syn-rift sediments, Northwestern Red Sea, Egypt
}

\author{
KHAIRY S ZAKY \\ Department of Geology, Minia University, El Minia 61519, Egypt. \\ e-mail: zakyk@yahoo.com
}

The present study focusses on field description of small normal fault zones in Upper Miocene-Pliocene sedimentary rocks on the northwestern side of the Red Sea, Egypt. The trend of these fault zones is mainly NW-SE. Paleostress analysis of 17 fault planes and slickenlines indicate that the tension direction is NE-SW. The minimum $(\sigma 3)$ and intermediate $(\sigma 2)$ paleostress axes are generally sub-horizontal and the maximum paleostress axis $(\sigma 1)$ is sub-vertical. The fault zones are composed of damage zones and fault core. The damage zone is characterized by subsidiary faults and fractures that are asymmetrically developed on the hanging wall and footwall of the main fault. The width of the damage zone varies for each fault depending on the lithology, amount of displacement and irregularity of the fault trace. The average ratio between the hanging wall and the footwall damage zones width is about $3: 1$. The fault core consists of fault gouge and breccia. It is generally concentrated in a narrow zone of $\sim 0.5$ to $\sim 8 \mathrm{~cm}$ width. The overall pattern of the fault core indicates that the width increases with increasing displacement. The faults with displacement $<1 \mathrm{~m}$ have fault cores ranging from 0.5 to $4.0 \mathrm{~cm}$, while the faults with displacements of $>2 \mathrm{~m}$ have fault cores ranging from 4.0 to $8.0 \mathrm{~cm}$. The fault zones are associated with sliver fault blocks, clay smear, segmented faults and fault lenses' structural features. These features are mechanically related to the growth and linkage of the fault arrays. The structural features may represent a neotectonic and indicate that the architecture of the fault zones is developed as several tectonic phases.

\section{Introduction}

The Upper Miocene-Pliocene sedimentary rocks are composed mainly of interbedded open marine sandstones and claystones of the Marsa Alam Formation; interbedded limestone, coarse sandstones, claystones and conglomerates of the Shagra Formation (Orszag-Sperber et al. 1998). These rocks are dissected by a NW-SE faults. Faults are generally described as zones consisting of a fault core and a surrounding damage zone, which differ structurally, mechanically and petrophysically from the undeformed host rock (Chester and Logan 1986;
Smith et al. 1990; Forster and Evans 1991; Chester et al. 1993; Bruhn et al. 1994; Caine et al. 1996). The fault core represents the part of the fault zone where most of the displacement is accommodated. It consists mainly of slip surfaces, gouge, breccia, cataclastic material, clay smears, horses and geochemically altered rock bodies (Chester and Logan 1986; Chester et al. 1993; Bruhn et al. 1994; Caine et al. 1996; Clausen 2002; Clausen et al. 2003). The damage zone is the deformed rock volume that surrounds the fault core and may be composed of subsidiary faults, fault blocks, veins, joints, stylolites, cleavage and folds (Chester and Logan 1986;

Keywords. Fault core; fault-damage zone; clay smear; segmented fault; Red Sea. 
Wu and Groshong 1991; Chester et al. 1993; Bruhn et al. 1994; Caine et al. 1996; Hesthammer et al. 2000; Jourde et al. 2002). Fault zones may have important implications for fluid flow in the earth's shallow crust as they commonly act as localized conduits or barriers (McCaig 1988; Sibson 1992, 1994, 1996; Sibson and Scott 1998).
The structural features within the fault zones are described in this work. Sliver fault block, segmented faults, fault lenses and clay smears represent the main structural features within the damage zone and fault core in the studied area. The structural features within the fault zones are mechanically related to the growth of the fault and may contain subsidiary faults or fracture networks

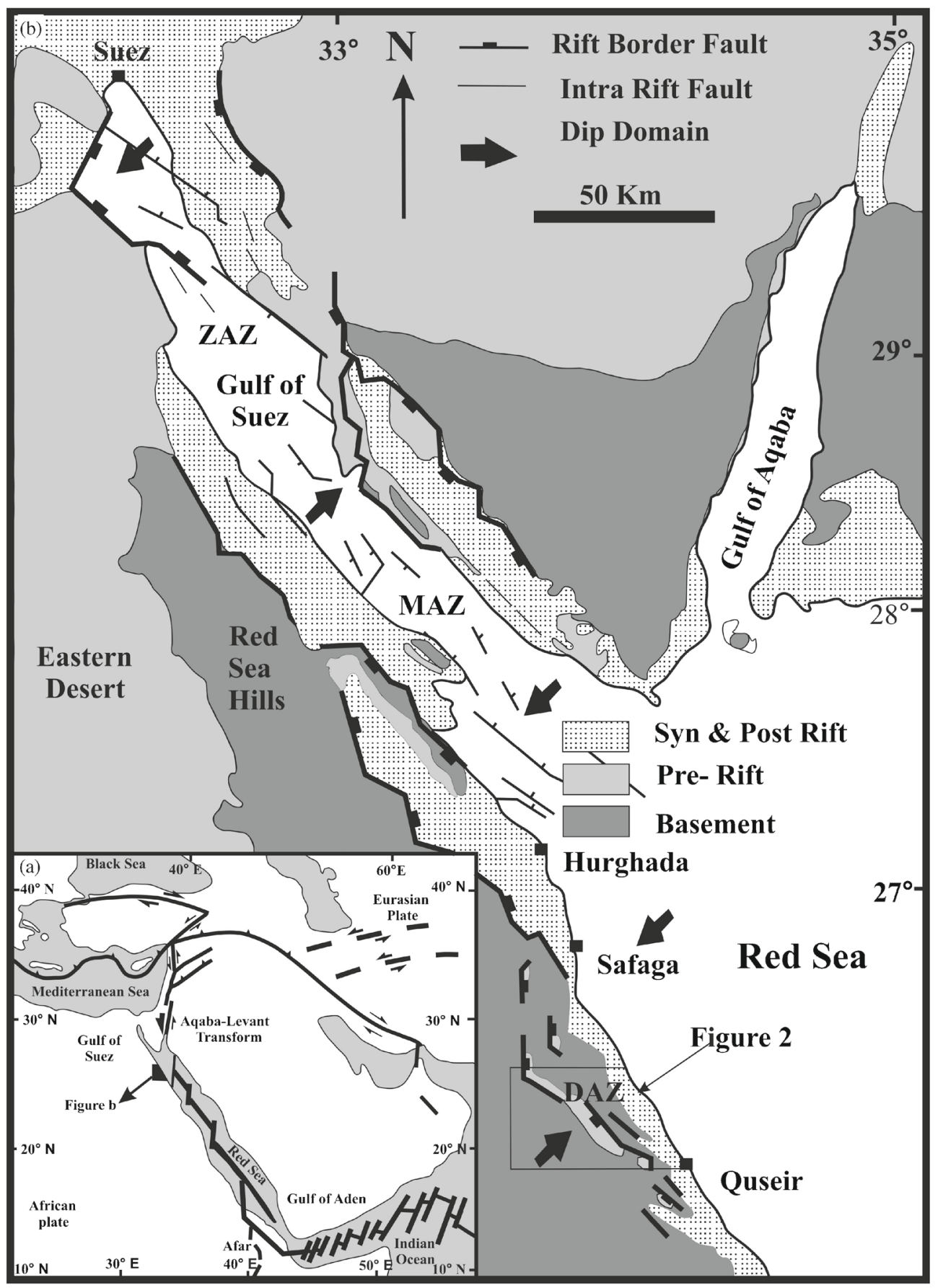

Figure 1. (a) Plate tectonic setting of the northwestern Red Sea rift system after Hempton (1987) and Khalil and McClay (2002), (b) principal structural elements of the northwestern Red Sea-Gulf of Suez rift system (after Khalil and McClay 2002). Bold arrows indicate the dominant stratal dip directions within the individual half-graben sub-basins. ZAZ, MAZ and DAZ are Zaafarana, Morgan and Duwi accommodation zones, respectively. 
(e.g., Sibson 1977; Caine et al. 1996). Small faults more commonly consist of isolated segments within a fault array, with fault propagation, i.e., layer/rheology controlled (Bastesen and Braathen 2010). Fault segmentation occurs on a wide range of scales (Stewart and Hancock 1991; Peacock and Sanderson 1994) and in a variety of tectonic settings (Aydin and Nur 1985; Morley et al. 1990). The fault growth occurs by coalescence of segments, horizontally (Cartwright et al. 1996; Willemse and Pollard 2000) and vertically (Childs et al. 1996; Mansfield and Cartwright 1996). Fault core in extensional, brittle faults frequently encompasses lozenge-shaped rock bodies, referred to as lenses or horses, which may occur in isolation, as en echelon trains, or be stacked to constitute duplexes (Gibbs 1983, 1984; Gabrielsen and Koestler 1987; Gabrielsen and Clausen 2001; Clausen et al. 2003). The high-strain zones separating individual fault lenses or groups of such lenses may include deformed lithologies derived from the foot wall and hanging wall (Lindanger et al. 2007). Fault lenses are common elements in extensional faults (e.g., Gibbs 1983, 1984; Childs et al. 1997; Gabrielsen and Clausen 2001; Lindanger et al. 2004). Clay smear develops from a combination of clay intrusion from source layers and from shearing within the fault zone (Lindsay et al. 1993; Lehner and Pilaar 1997; Bense et al. 2003; Van der Zee and Urai 2005) and laboratory experiments (Sperrevik et al. 2000; Clausen and Gabrielsen 2002). The history of faulting and lithology may play an important role in the complex architecture of the fault zone (Mandl 2000; Heermance et al. 2003).

In this paper, I examine several small normal fault zones in Upper Miocene-Pliocene rocks on the northwestern side of the Red Sea, with varying displacement from $<1$ to $>2 \mathrm{~m}$ in order to explain the architectures of these zones. I present an analysis of damage zones and fault cores of these faults. The focus is on the relationships between (1) the width of the fault core, the damage zone, and the fault throws, (2) fracture density, width of the damage zones, and lithology and (3) describe the

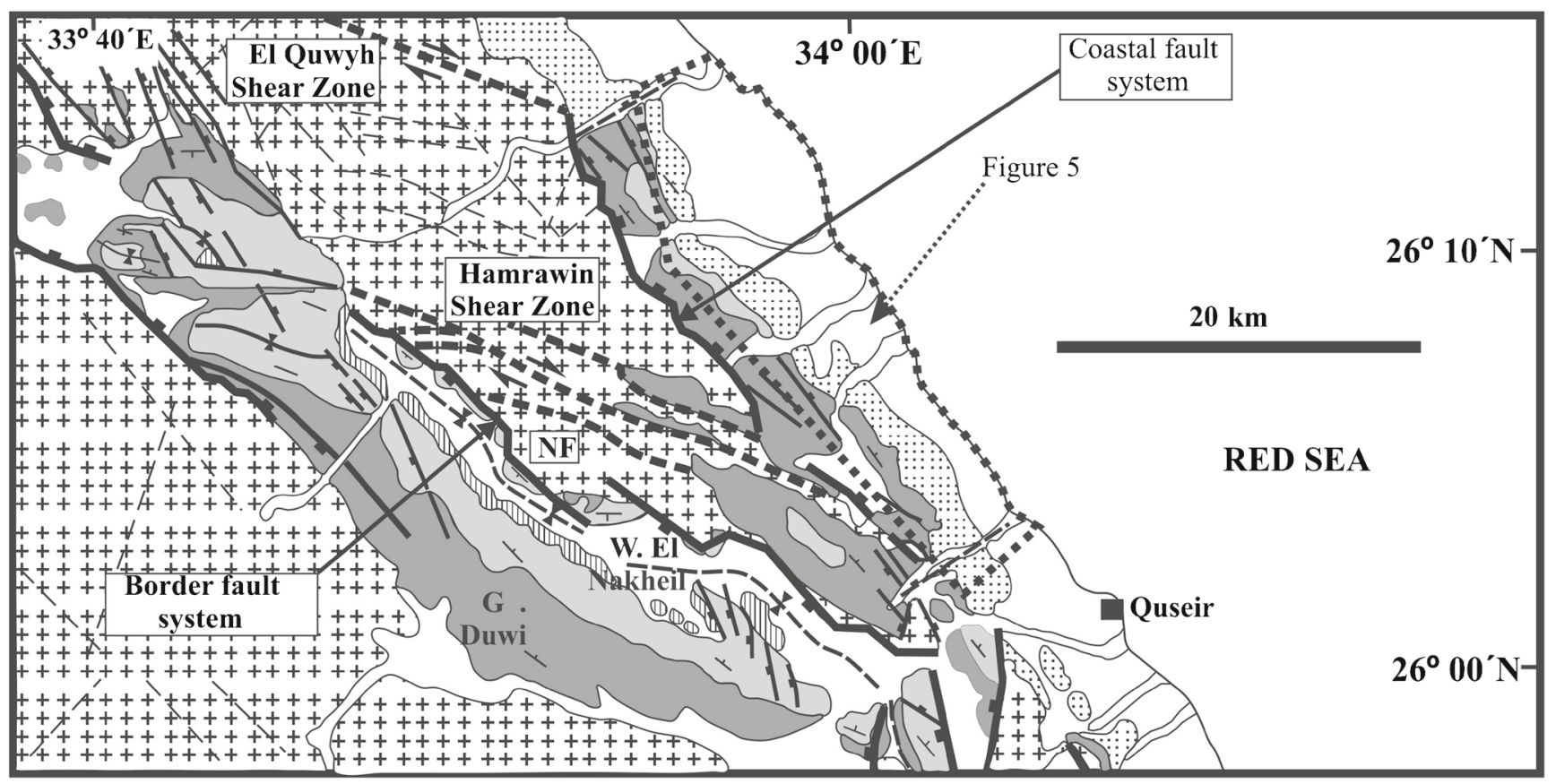

\begin{tabular}{|c|c|c|c|c|}
\hline & Pliocene \& Quaternary & \multirow{3}{*}{ Syn-Rift } & \multirow{3}{*}{$\frac{a}{-\vec{a}}$} & Major Extensional Fault \\
\hline 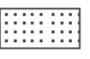 & Miocene & & & $\begin{array}{l}\text { Extensional Fault } \\
\text { Precambrian Shear Zone }\end{array}$ \\
\hline 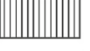 & Upper Oligocene (Nakheil) & & & Basement Fault Zone \\
\hline & Eocene & & $\mathrm{Y}$ & Syncline \\
\hline 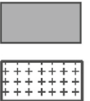 & $\begin{array}{l}\text { Cretaceous-Paleocene } \\
\text { Precambrian Basement }\end{array}$ & Pre-Rift & - & $\begin{array}{l}\text { Dip \& Strike } \\
\text { of strata }\end{array}$ \\
\hline
\end{tabular}

Figure 2. Simplified geological map of the northwestern Red Sea. NF indicates the Nakheil fault segments of the border fault system. Redrawn after Khalil and McClay (2002). 
structural features associated with the fault zones as a neotectonics.

\section{Structural framework of the northwestern Red Sea margin}

The Red Sea is a relatively young and active continental rift system that initiated in the Late Oligocene-Early Miocene (Mckenzie et al. 1970; Le Pichon and Francheteau 1978; Cochran 1983; Steckler et al. 1988; Coleman 1993; Bosworth et al.
2005). It formed in response to the northeast separation of the Arabian plate away from the African plate (Girdler and Southren 1987; Hempton 1987; Joffe and Garfunkel 1987; Coleman 1993). By the Late Middle Miocene, the opening of the Red Sea was linked to sinistral strike-slip displacements along the Gulf of Aqaba-Dead Sea transform fault system (figure 1a; Freund 1970; Mckenzie et al. 1970; Ben-Menahem et al. 1976; Quennell 1984; Steckler et al. 1988; Morgan 1998; Abdel Khalek et al. 1993; Bosworth et al. 2005). The extension direction was $\mathrm{N} 60^{\circ} \mathrm{E}$ from the Late Oligocene
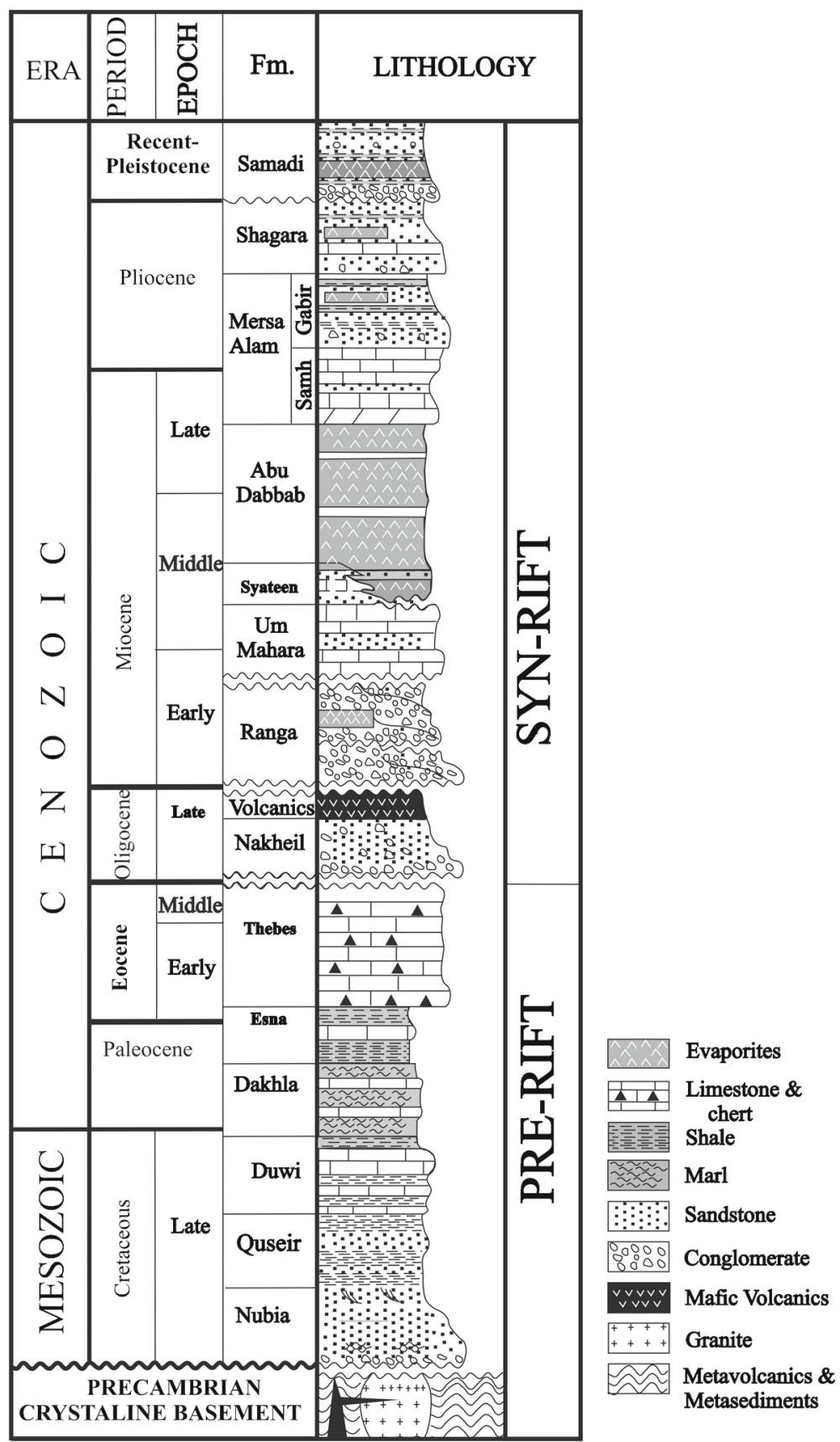

Figure 3. Summary stratigraphy of the northwestern Red Sea rift system. Data from Said (1990), Purser and Bosence (1998) and Khalil and McClay (2002). 
through the Miocene (Bosworth and McClay 2001). The pre-existing basement fault zones such as NW-trending shear zones were reactivated during the Late Oligocene-Miocene extension (Dixon et al. 1987; Moustafa 1997; Younes et al. 1998; Younes and McClay 2001). These Precambrian fault zones strongly controlled the orientations of the Cenozoic rift faults. The northwestern Red Sea-Gulf of Suez rift consists of four distinct subbasins (with half-graben geometries) separated by complex accommodation zones (figure 1b). Two extensional fault systems, as well as a number of NW and WNW half graben, were discussed in the northwestern margin of the Red Sea (Khalil and McClay 2009). The western fault system juxtaposes the pre-rift sedimentary rocks against Precambrian basement in the footwall, while the eastern fault system generally trends NW, subparallel to the shoreline and delineates the syn-rift exposures along the Red Sea coast. The western fault system is strongly segmented and trends oblique to the rift trend, reflecting the inherited basement fabric (Khalil and McClay 2002, 2004). Both of these fault systems consist dominantly of NW, WNW and NS fault segments that are linked together and form a zigzag fault pattern that bounds rhomboidal fault blocks (figure 2).

\section{Geology}

Pre-rift sedimentary rocks of the northwestern part of the Red Sea range in age from Upper Cretaceous to Lower Eocene. They are unconformably overlain by syn-rift sediments. The oldest synrift sediments at the northwestern Red Sea are lacustrine red mudstones, sandstone, breccias and conglomerates of the Nakheil Formation (figure 3). The Nakheil Formation is Late Oligocene in age (Akkad and Dardir 1966; Said 1990) and is locally preserved in small hanging wall synclines formed along the Border Fault system. The thickness of Nakheil Formation is $60-120 \mathrm{~m}$ and it unconformably overlies the pre-rift Eocene Thebes Formation. The Nakheil breccias and conglomerates consist of reworked chert and limestone clasts derived from the underlying Eocene Thebes Formation. The coarse-grained sandstones and conglomerates of the Aquitanian-Burdigalian age Ranga Formation (El Bassyony 1982), Oligocene to Middle Miocene (Hermina et al. 1989), form a distinct syn-rift unit that unconformably overlies the prerift rocks and in places also overlies the Upper Oligocene syn-rift red clastics. Its lower part consists of continental red sandstones and conglomerates locally interbedded with a few gypsum thin beds and marls which contain Late AquitanianBurdigalian fauna referred as Rosa Member (Philobbos and El-Hadded 1983). The upper part of the Ranga Formation consists of shallow marine conglomerates and sandstones containing oyster shell fragments and patch reefs (Khalil and McClay 2009). Unconformably overlying the Ranga conglomerates are reefal limestones and shallow marine fine-grained clastics of the Late BurdigalianLanghian Um Mahara Formation (El Bassyony 1982; Said 1990). The Middle-Late Miocene evaporite sequence of the Abu Dabbab Formation unconformably overlies the older syn-rift and pre-rift strata. It consists of massive to poorly bedded gypsum outcropping along the coastal plain, and it is up to $3 \mathrm{~km}$ in the offshore area

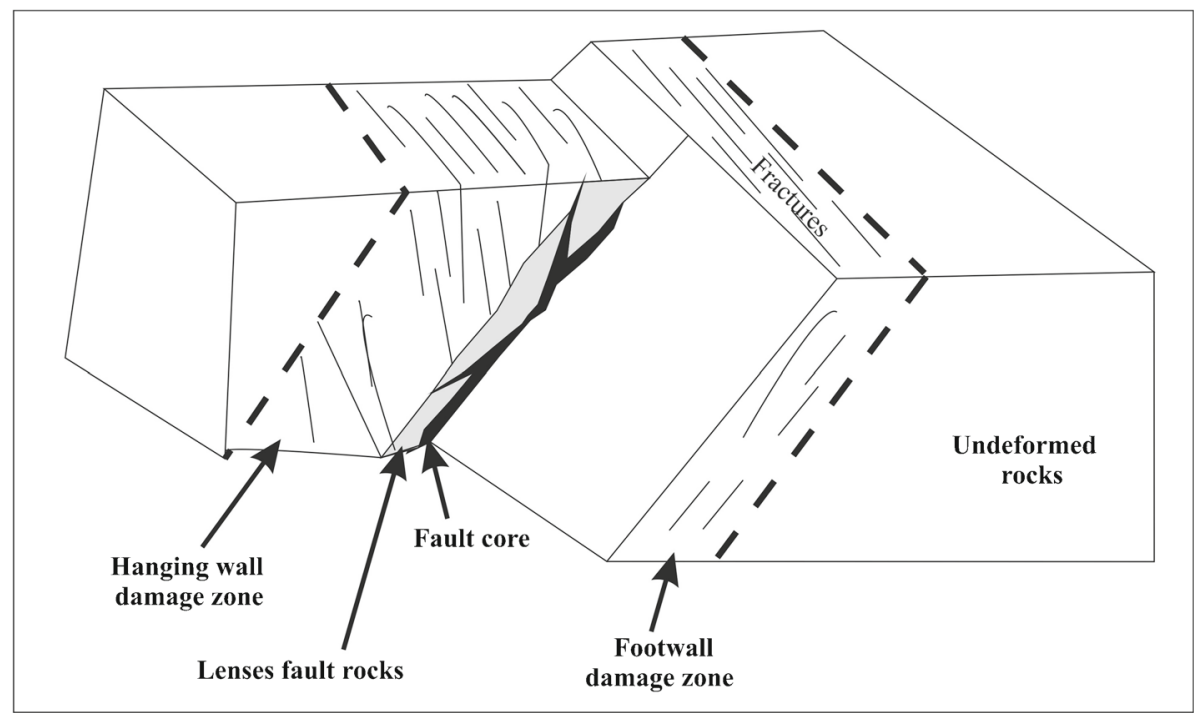

Figure 4. Sketch showing some structural elements commonly identified in fault zones. 
(Tewfik and Ayyad 1982; Said 1990). Overlying the evaporite sequence is a $200-$ to $300-\mathrm{m}$ thick succession of Upper Miocene-Quaternary sediments that are exposed along the coastal plain. These sediments can be up to $1000-\mathrm{m}$ thick in the offshore (Orszag-Sperber et al. 1998; Heath et al. 1999). They include Upper Miocene-Pliocene shallow to open marine sandstones and claystones of the Marsa Alam Formation, interbedded limestone, coarse sandstones and conglomerates of the Shagara Formation, as well as Pleistocene conglomerates and coarse sands of the Samadi Formation.

\section{Methods}

Small normal faults are well exposed in the Upper Miocene-Pliocene sedimentary rocks along several ENE-oriented valleys in the study area. These valleys are oriented nearly perpendicular to the strike of these faults. The azimuth of 49 faults

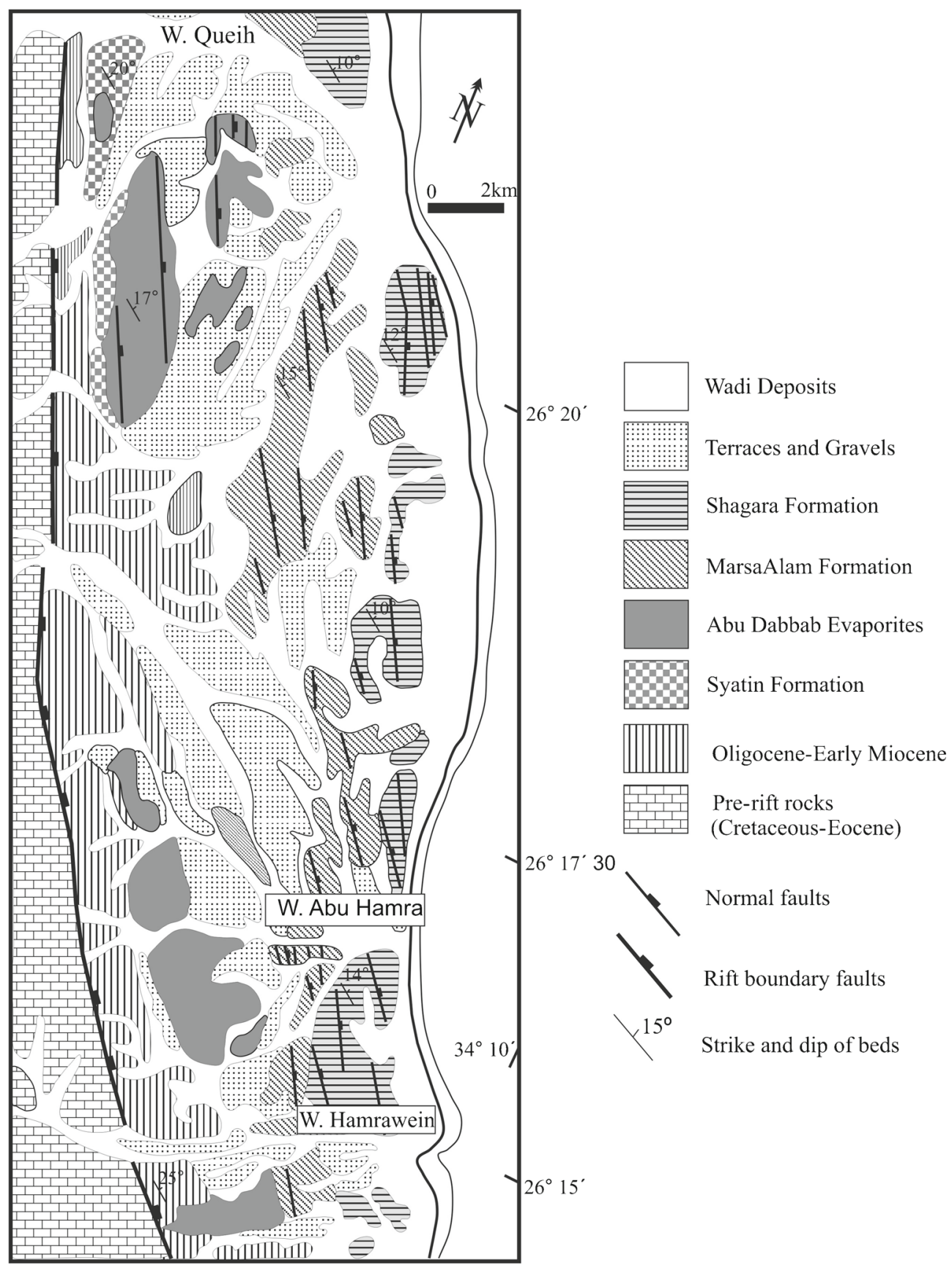

Figure 5. Detailed geological map of the study area show the main rock units and main structural elements. The major NW-SE normal fault spate the syn-rift rocks (hanging wall) from pre-rift rocks (footwall). Syn-rift rocks are dissected by small normal faults. See figure 2 for location. 
and the displacement along the fault planes are measured carefully. The attitude (dip and dip direction) of 17 fault planes and slickenlines are measured to determine the orientation of the paleostress axes $(\sigma 1, \sigma 2, \sigma 3)$ and the ratio of principal stress differences $R=(\sigma 2-\sigma 3) /(\sigma 1-\sigma 3)$. Paleostress was determined using an improved version of the right-dihedral method of Angelier and Mechler (1977), and a rotational optimization method, using the TENSOR program developed by Delvaux (1993) and Delvaux and Sperner (2003). The thickness of fault cores and damage zones (figure 4) (hanging wall and footwall damage zones) are measured along 30 fault zones. Due to variations in lithology along the faults, the thickness of the fault core and the damage zones were measured in several places along individual fault outcrops, covering the maximum and minimum thicknesses. The data used in this study were obtained directly through the field survey of vertical sections along the ENE-WSW valleys by means of conventional structural techniques (Brunton compass, tape and GPS), digital imaging, and fault zone mapping.

\section{Structural analysis of the study area}

The Miocene-Pliocene sedimentary rocks in the study area (figure 5) have average dips of $12^{\circ}$ towards the northeast (figure 6a, b). These rocks are dissected by several macro-scale and small fault zones. The macro-scale faults were easily detected on aerial photographs and landsat images. The main trends of these faults are NW-SE to NNWSSE, NE-SW and WNW-ESE striking faults (figure 6c). These structural trends inherited from the Precambrian-Paleozoic basement (Montenat et al. 1998). The NW-SE to NNW-SSE faults are mainly normal faults parallel to the Red Sea and dip to northeast and southwest directions. The WNWESE striking faults play the most significant role in modifying Miocene fault geometry (Younes and McClay 2001; Khalil and McClay 2009).

Small fault zones are exposed in ENE vertical exposures along Queh, Hamarwan, and Abu Hamra valleys, as well as other small valleys (figure $5)$. These fault zones are mainly normal and are concentrated inside Marsa Alam (Upper MiocenePliocene) and Shagra (Pliocene) formations. The fault zones form parallel step faults and sometimes structural grabens (figure $7 \mathrm{a}, \mathrm{b}$ ). They have a geometry characterized by straight and slightly curved fault segments (figure 8). The curvature path of the faults is probably due to the changes in lithology.

The slickenlines are recorded on a number of fault planes (figure 9a). The attitude of slickenlines
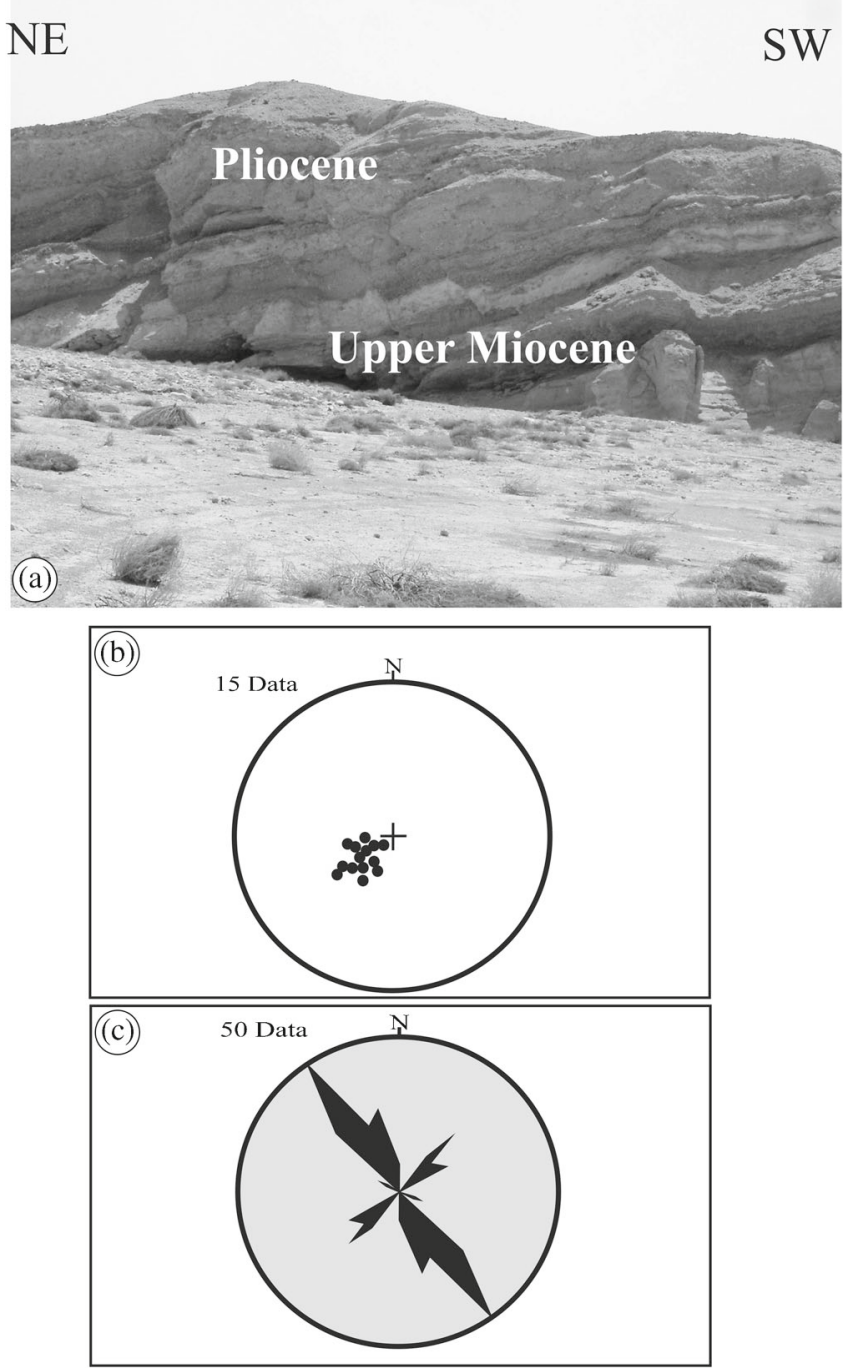

Figure 6. (a) Field photograph showing northeast dip of the Miocene-Pliocene sedimentary rocks, looking SE. (b) Lower hemisphere equal area stereogram of bedding poles in the study area. (c) Rose diagram of the macro-scale normal faults in Miocene-Pliocene rocks.

has been used to determine the orientation of slip and the sense of relative motion along the fault planes. Seventeen fault planes with a clear sense of movement are selected to determine the orientation of the paleostress axes $(\sigma 1, \sigma 2, \sigma 3)$. The attitude (strike and dip) of the fault planes and the attitude (trend and plunge) of the slickenlines were collected on these faults. The paleostress results (figure $9 \mathrm{~b}$ ) indicate that the minimum $(\sigma 3)$ and intermediate $(\sigma 2)$ paleostress axes are generally sub-horizontal and the maximum paleostress axis $(\sigma 1)$ is sub-vertical.

Forty-nine of the $290^{\circ}-345^{\circ} \mathrm{N}$ oriented small fault zones are chosen to study the fault zone architecture in the Upper Miocene-Pliocene rocks (figure 9c). These faults dip toward the NE and SW with an average angle of $68^{\circ}$ and $61^{\circ}$, respectively 

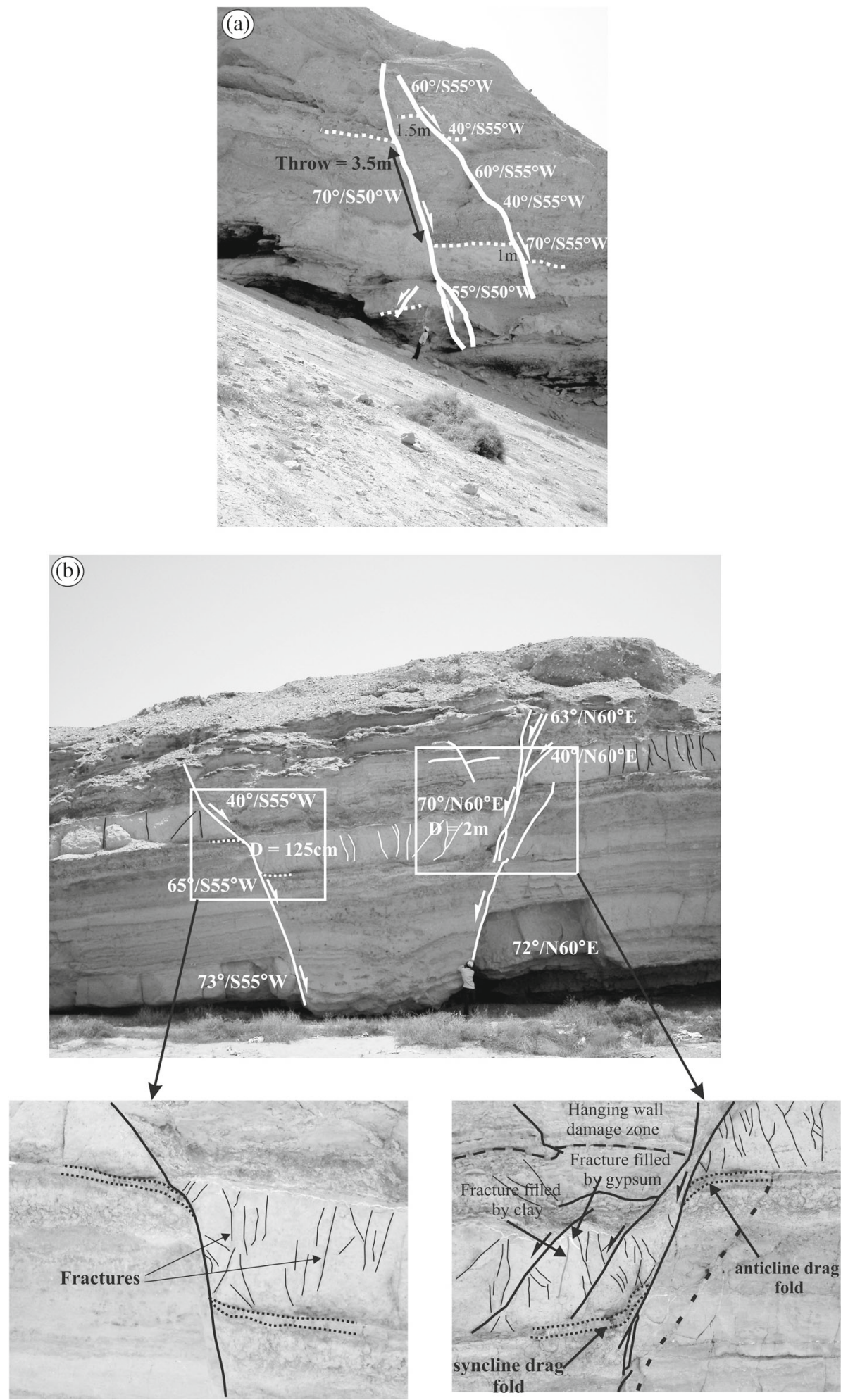

Figure 7. Field photograph showing (a) parallel step faults and (b) graben in the Upper Miocene-Pliocene rocks. The two windows in the bottom show the fracture density in the hanging wall damage zone is more than the fracture density in the footwall damage zone.

(figure 9d). The dip separation distances of the NW-oriented normal faults, which dip towards the $\mathrm{NE}$, range from 7 to $300 \mathrm{~cm}$, with an average of $80 \mathrm{~cm}$, while the dip separation distances of the
NW-oriented normal faults, which dip towards the SW, range from 10 to $400 \mathrm{~cm}$ with an average of $51 \mathrm{~cm}$. The small fault zones are nearly parallel to macro-scale normal faults. 

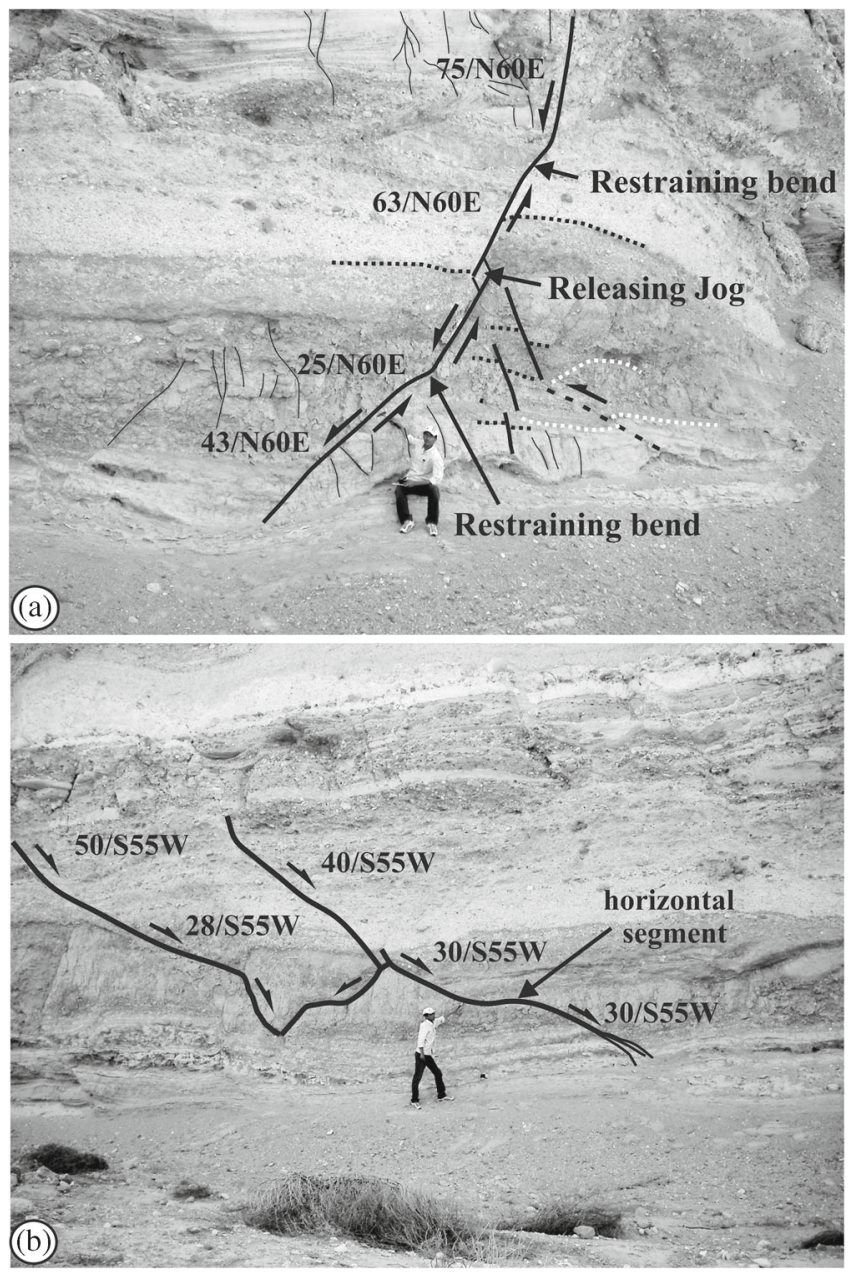

Figure 8. Small NE dipping normal fault with $1 \mathrm{~m}$ displacement. (a) Dip of the fault changes from top to bottom, probably due to change in lithology. Notice the releasing jog and restraining bends along the segments of this fault. SW dipping curved small normal fault. (b) The displacement changes from one segment to another.

\section{Fault zone analysis}

The NW-SE small fault zones in Upper MiocenePliocene sedimentary rocks, along the northwestern margin of the Red Sea, show a large variety of structures. These fault zones consist mainly of fault core and damage zones. The fault core and damage zones are measured along 30 fault zones. The fault core is formed of gouge and breccia with occasional gypsum veins. Damage zones gradually fade outward into intact host-rock. Their distinction from the host-rock is based on the change in the density and geometry of fault-related fractures, although the boundary is gradual. The detailed descriptions of the damage zones and fault cores are shown in the following sections.

\subsection{Damage zones}

Damage zones along the investigated small normal faults include hanging wall and footwall damage zones. They are commonly defined by the occurrences of asymmetric subsidiary faults, fractures and sometimes drag folds. The subsidiary faults and fractures are both synthetic and antithetic to the faults and they typically strike parallel or subparallel to the fault. The slip surfaces along the subsidiary faults have a dominant dip-slip displacement and there is no indication of lateral slip. A few numbers of fractures have different directions. These fractures are closed and look like shear fractures, but the lateral displacement along them is not clear. The fracture distribution is somewhat different across the foot and hanging wall damage zones. The hanging wall damage zones are wider and display a larger number of fractures than the footwall damage zone (figure 10a, b and c). The average ratio between hanging wall and footwall damage zones width is about $3: 1$. The field observations and measurements show that the width of the damage zone varies along different faults developed within Upper Miocene-Pliocene sedimentary rocks which are based on the amount of displacement. A direct relationship exists between the width of the hanging wall damage zones and displacement along the master fault (figure 12a).

\subsection{Fault cores}

Fault cores in the studied fault zones are up to a few centimetre wide and are composed mainly of gouge, breccia and sometimes membranes of gypsum veins (figures 10a, b, c and 11). The gouge probably developed as a result of shearing and the smearing of plastic claystone into the fault core. The thickness of the fault cores increases with increasing displacement (figure 12b). For displacement $<1 \mathrm{~m}$, the fault cores are discontinuous and display thicknesses between 0.5 and $\sim 4 \mathrm{~cm}$, while for faults with displacement up to $2 \mathrm{~m}$, the fault cores are approximately continuous and display thicknesses between $\sim 4$ and $8 \mathrm{~cm}$. In some cases, the fault core thickness is more than $8 \mathrm{~cm}$ and consists of a variety of fault rocks and entrained bodies of rocks (figure 13) that probably indicates considerable variation in strain intensity and deformation style. The fault core and damage zone are separated by a slip surface, upon which all the displacement localises. In other cases, this transition may be gradual, forming a fault core-damage zone transition.

\section{Structural features associated with the fault zones}

The studied fault zones have a number of structural features. These features are represented by sliver fault blocks, segmented faults, fault lenses 

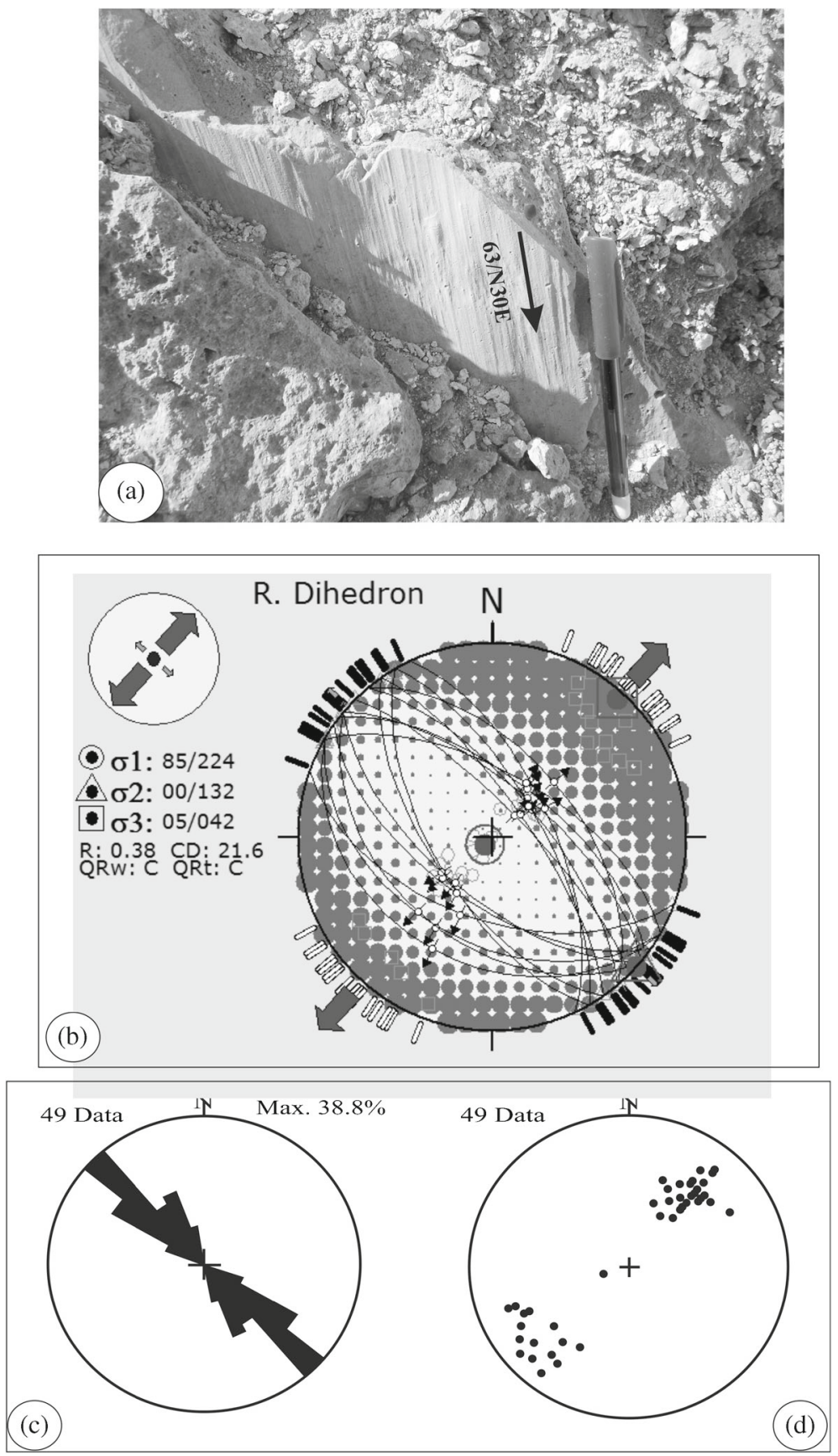

Figure 9. (a) Example of slickenlines as a sense of movement indicator on small normal fault planes in the study area. (b) Lower hemisphere, equal area projection, of small fault planes, observed slip lines and slip senses; circles, triangles and squares $=$ symbols of stress axes $\sigma 1, \sigma 2$ and $\sigma 3$ (S1, S2 and S3). $R=$ stress ratio. (c and d) Rose diagram and Lower hemisphere, equal area stereoplot of small faults in Upper Miocene-Pliocene rocks, used for studying the fault damage zones.

and clay smears. They are mechanically related to the growth and linkage of the fault arrays and represent a neotectonics in the northwestern Red Sea. The descriptions of these features are given in the following paragraphs.

\subsection{Sliver fault blocks}

The deformed zone between two small normal faults is called as sliver fault block. This structure is composed of rotated fault blocks; antithetic; synthetic normal faults; and drag folds (figure 14a, b). The sliver block between faults, no. 1 and no. 2 , in figure $16(\mathrm{a})$ is rotated $12^{\circ}$ clockwise. This rotation was a result of the movement along the two normal faults. A number of minor $45^{\circ} / \mathrm{N} 55^{\circ} \mathrm{E}$ antithetic normal faults dissected this block (figures 15, 16a). The displacement along these minor faults increased the clockwise rotation of the beds within the sliver fault block. 

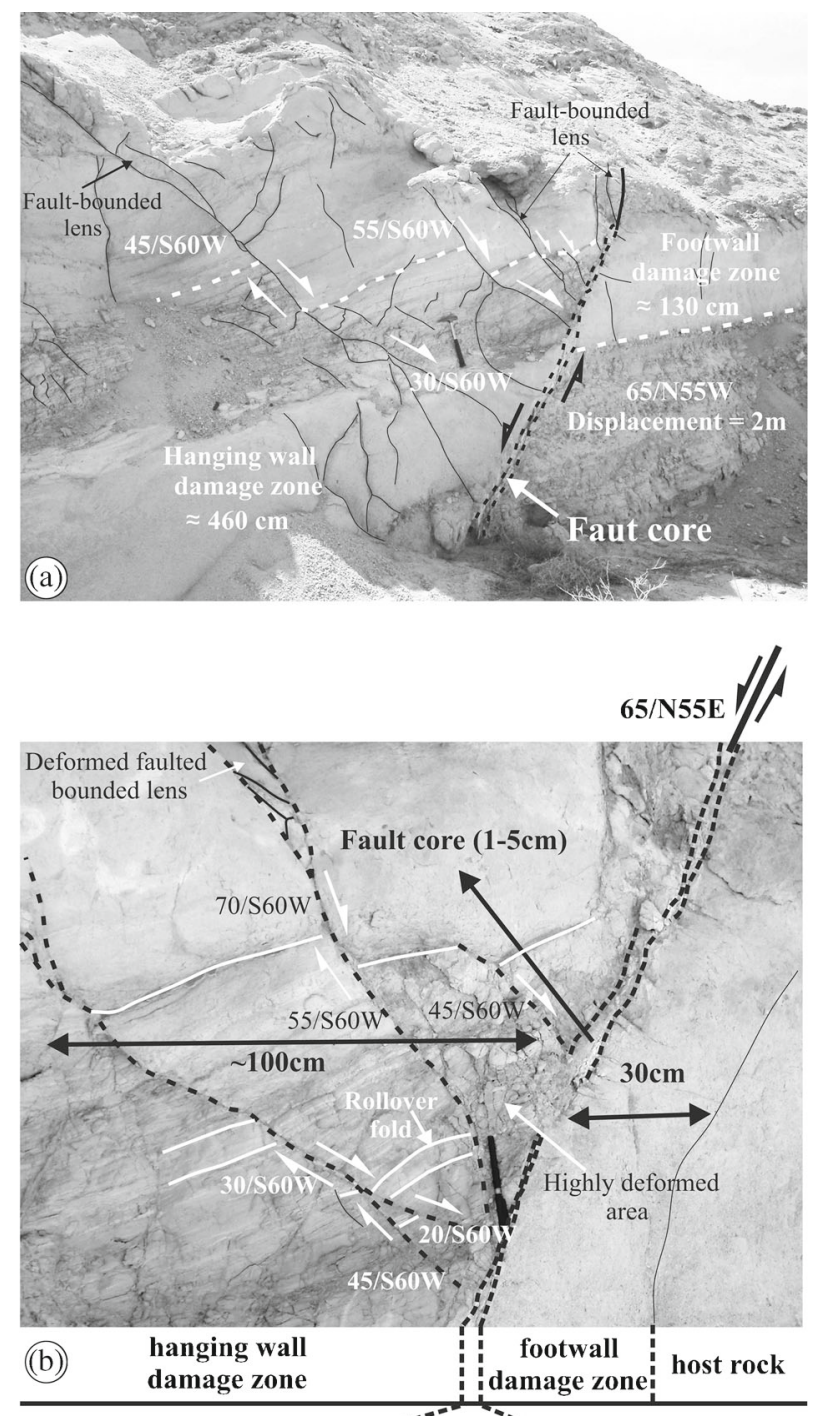

íFault corèi

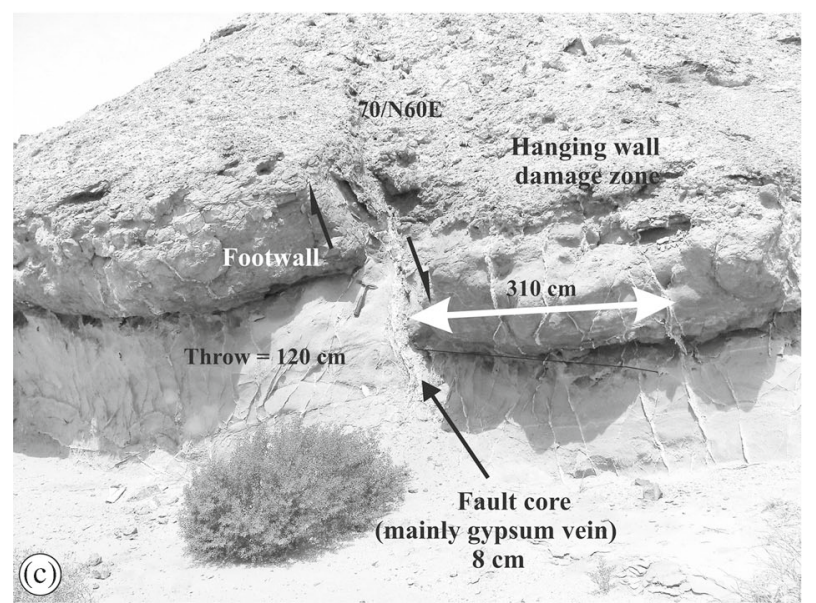

Figure 10. (a) Field photograph showing the damage zones of a small NW-oriented normal fault. The hanging wall damage zone is wider and highly fractured than the footwall damage zone. Fault core is ranging from 5 to $8 \mathrm{~cm}$. Fault-bounded lenses are present along the main fault and the antithetic subsidiary faults. Synthetic, antithetic and vertical joints are present in the hanging wall damage zone. (b) Field photograph showing hanging wall damage zone along $65^{\circ} / \mathrm{N} 55^{\circ} \mathrm{E}$ small normal fault. Fault core ranges from 1 to $5 \mathrm{~cm}$. Deformed rock lenses are present between the main fault and antithetic faults. Notice the rollover fold along the hanging wall of the $30^{\circ} / \mathrm{S} 60^{\circ} \mathrm{W}$ antithetic subsidiary fault. (c) Field photograph showing the damage zones of a $70 / \mathrm{N} 60^{\circ} \mathrm{E}$ small normal fault. The hanging wall damage zone is represented mainly by synthetic gypsum veins. The average thickness of fault core is about $8 \mathrm{~cm}$ and consists mainly of gypsum. Hammer serves as scale. 


\subsection{Segmented faults}

The fault zones and the subsidiary faults generally consist of isolated segments in the studied area. These segments have the same orientation and dip exposed in a vertical cliff section (figures $7 \mathrm{~b}, 14 \mathrm{a}$ ). The cliff section consists mainly of repetition of sandstone and claystone rocks. The competence contrast between these rocks may have caused the segmentation of the faults. The same result is concluded by Bastesen and Braathen (2010). They mentioned that the fault segmentation is controlled by layer/rheology.

\subsection{Fault lenses}

The fault lenses are observed along the main and subsidiary faults in damage zones and sliver fault blocks. These lenses are developed by faultsegments linkage and by tip bifurcation of the faults (figures 10a, b, 16). Asperity-related lenses may become thin and tight. The shapes of these lenses vary from long lenses with one tip to small lenses with two tips and sometimes they appear as semicircular bodies. The material inside the lens may become more deformed than the surrounding rock (figure 10b).

\subsection{Clay smears}

The term 'clay smears' include all processes that somehow transform claystone or mudstone in the wall rock into clay in the fault rocks. Clays are common constituents of fault rocks in the studied fault zones. The clay smears are recorded along main and subsidiary faults (figure 16). The clay smears in the fault rocks are probably due to abrasion movement of claystone past sandstones and shearing deformation between hanging wall and footwall cut-offs of claystone beds.

Permeability can be reduced by as much as seven orders of magnitude due to the incorporation of clay in fault rocks (Crawford et al. 2002; Davatzes and Hickman 2005). Smearing of low-permeability clay is one of the most important conditions promoting fault sealing (e.g., Caine et al. 1996), and so assessment of fault smear distribution is of key importance for evaluating the fluid connectivity of hydrocarbon reservoirs and groundwater systems alike.

\section{Discussion}

The examined small normal fault zones are concentrated inside the Marsa Alam (Late Miocene) and Shagra (Pliocene) formations. The azimuth of these faults ranges from $295^{\circ}$ to $345^{\circ} \mathrm{N}$. These faults dip toward the NE and SW. The paleostress analysis of 17 fault planes bearing slickenlines indicates that the minimum $(\sigma 3)$ and intermediate $(\sigma 2)$ paleostress axes are generally sub-horizontal and the maximum paleostress axis

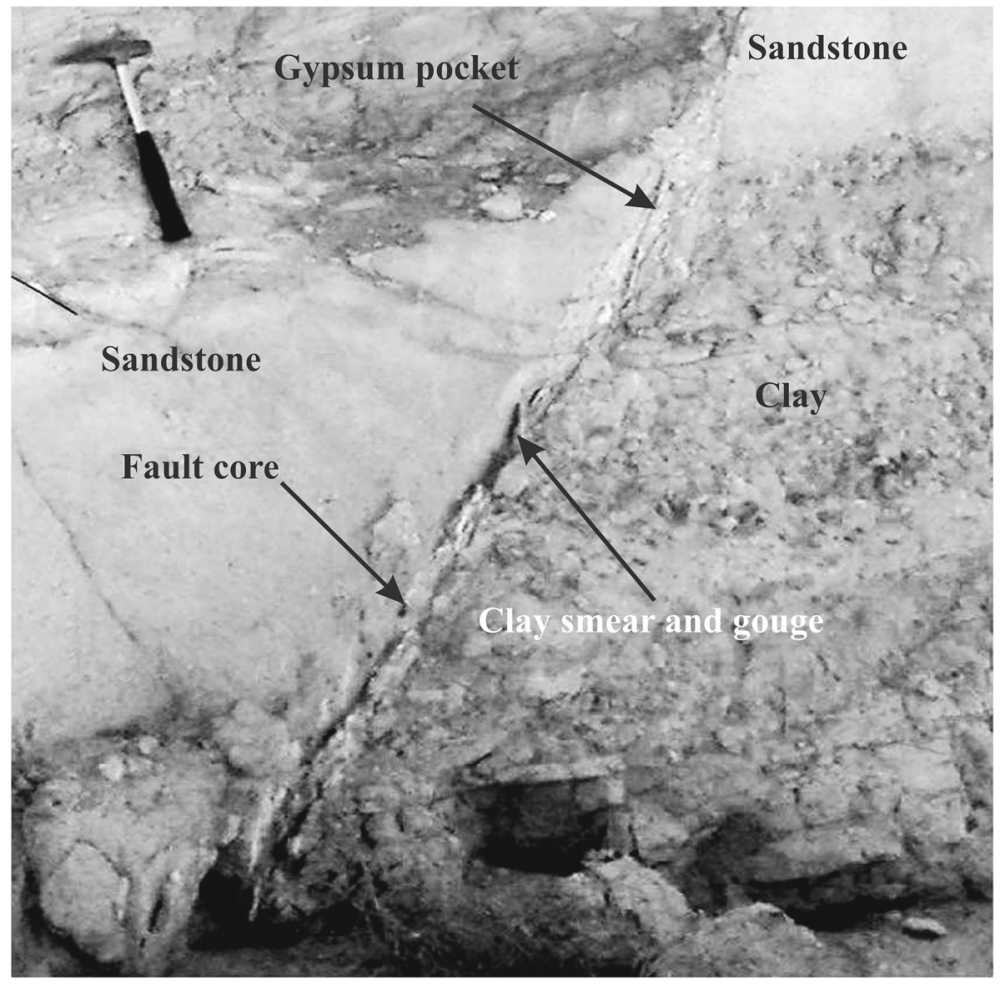

Figure 11. Photograph showing fault core, which consists of gypsum pocket and gouge. 

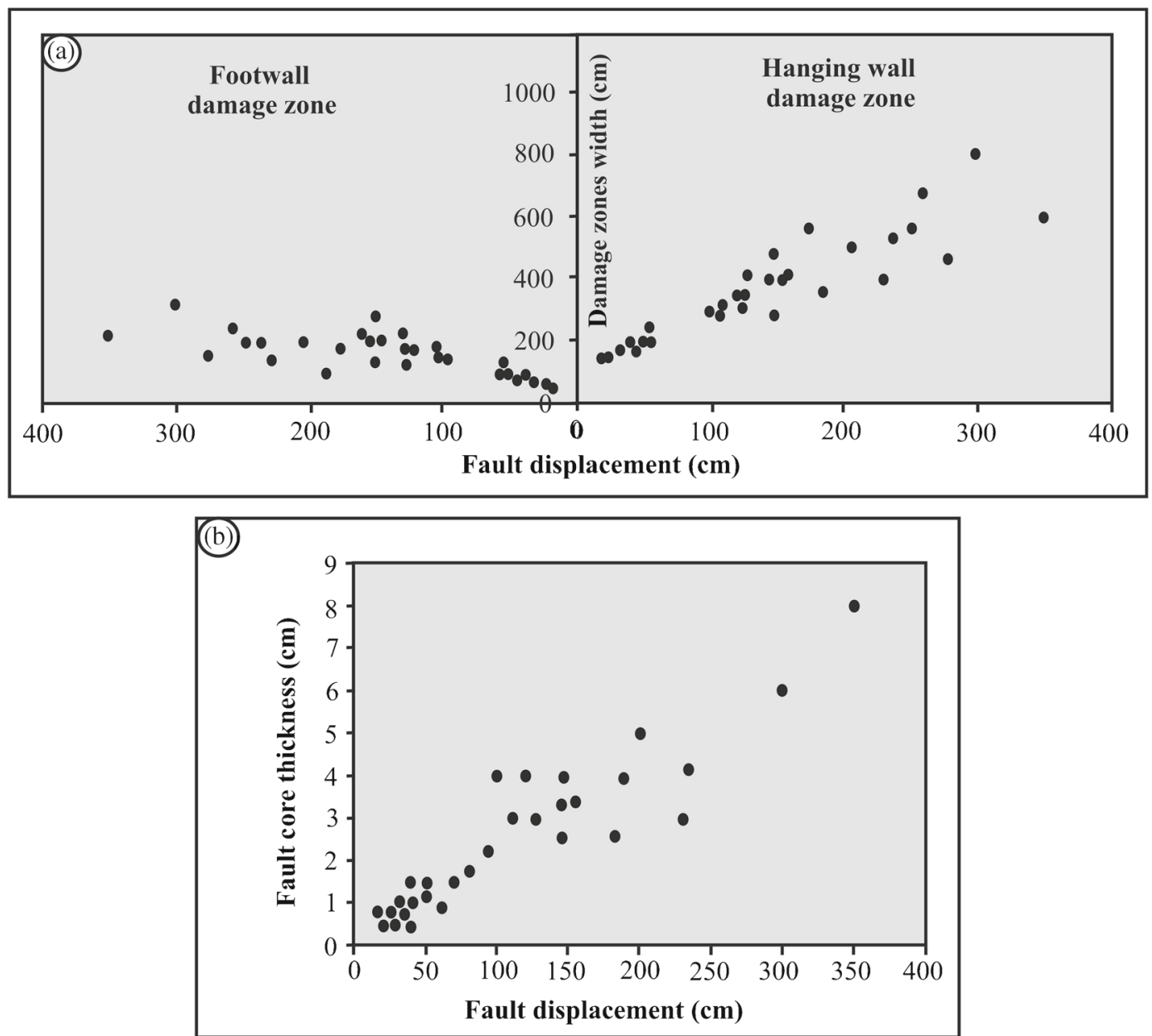

Figure 12. Fault displacement vs. hanging wall damage zone (a) width and (b) vs. fault core thickness.

$(\sigma 1)$ is sub-vertical. The same result is concluded by many authors (e.g., Lyberis 1988; Bosworth and Taviani 1996; Bosworth and Strecker 1997; Bosworth and McClay 2001; Bojar et al. 2002).

The architecture of the small normal fault zones indicates that they consist mainly of damage zones and fault core. Analysis of the damage zones indicates asymmetric damage zones. The hanging wall damage zones are wider than the footwall and are characterized by densely spaced fractures and subsidiary faults, synthetic or antithetic to the fault (figures 10a, b, c and 14b). The average ratio between the hanging wall and footwall damage zone's width is about $3: 1$. An asymmetric deformation pattern across normal faults is also described elsewhere in many different geological settings and on a range of scales (Aydin and Johnson 1978; Koestler and Ehrmann 1991; Antonellini and Aydin 1995; Knott et al. 1996; Aarland and Skjerven 1998; Hesthammer and Fossen 1998; Gabrielsen et al. 1998; Nelson et al. 1999; Mitra and Ismat 2001). This deformation pattern across normal fault zones may be a result of asymmetric strain distribution along the fault.
The sandstone rocks along the fault zones are affected by a large number of fractures and subsidiary faults than the claystone rocks (figure 10a). The same observations are concluded by Peacock and Zhang (1993) and Ouenes (2000). They mentioned the fracture distribution show a close relationship to lithology. This probably indicates that the asymmetric strain distribution along the studied fault zones is controlled by lithology.

The width of the damage zones was found to increase proportionally with displacement (figure 12a). Several authors have shown a positive correlation between damage zone width and displacement (Knott 1994; Knott et al. 1996; Beach et al. 1997, 1999; Fossen and Hesthammer 2000; Shipton and Cowie 2001).

The damage zones along the curved fault planes (figure 8a) are wider than the damage zone along planar faults (figure 7a).

The present study indicates that the fault core thickness increases with increasing displacement along the faults. For displacement below $2 \mathrm{~m}$, the fault cores display thicknesses between 0.5 and $\sim 4 \mathrm{~cm}$, while faults with displacements of more 


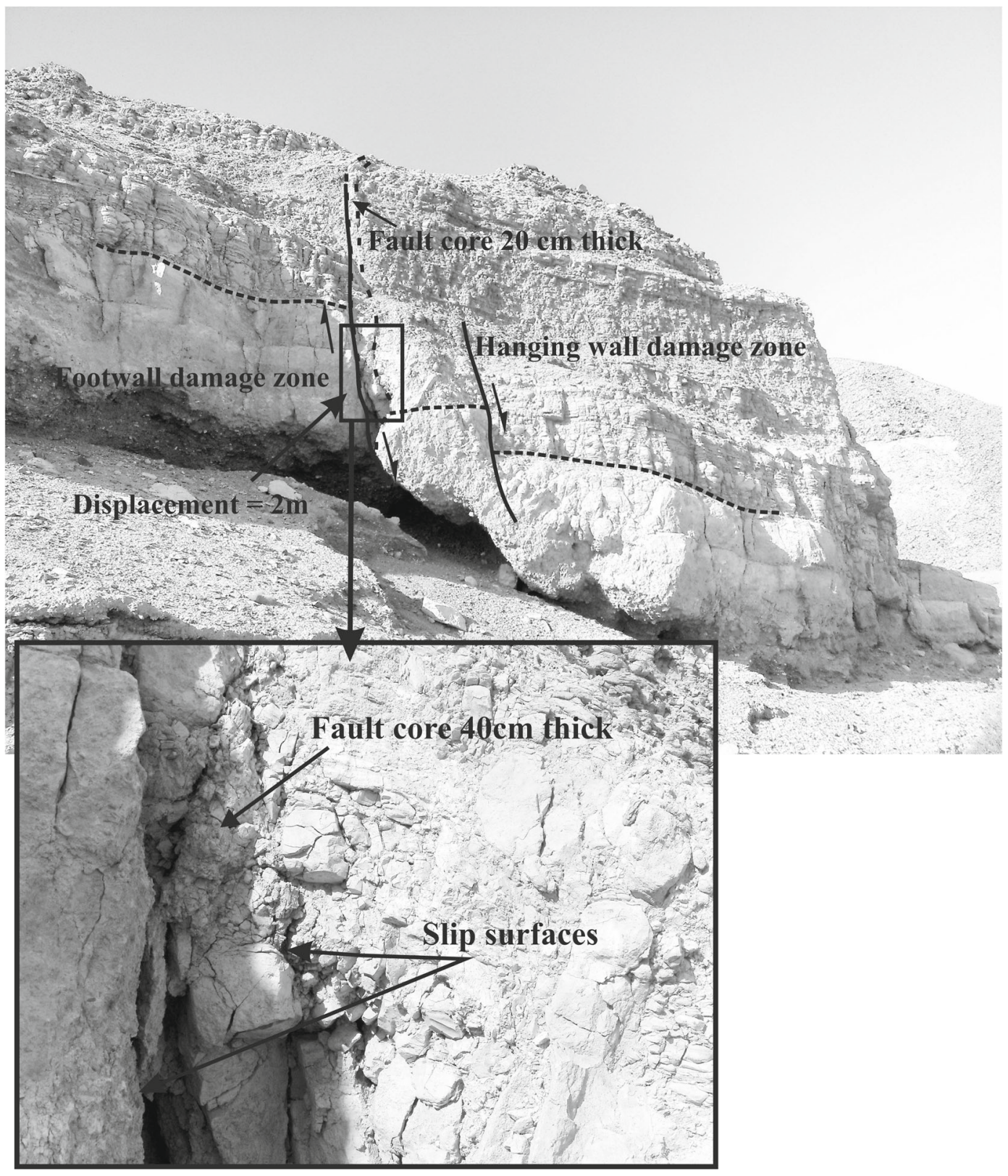

Figure 13. Field photograph showing fault core, which consists of a variety of fault rocks and entrained bodies of rocks. Close-up view shows the thickness of the fault core and main slip surfaces.

than $2 \mathrm{~m}$, display fault core thicknesses between $\sim 4$ and $8 \mathrm{~cm}$. The variations in the fault core of the studied small normal faults are not great. This may be related to the small displacements along the studied faults and most of the studied faults are planar faults.

The studied fault zones are associated with a number of structural features, which may be a neotectonics in the northwestern Red Sea. These features are mechanically related to the growth and linkage of the fault arrays. This means that the fault zone architectures in the northwestern Red Sea are developed as several tectonic phases.
The first structural feature recorded in the fault zones is sliver fault blocks. This feature is a deformed zone between two small normal faults. The deformed zone is composed of rotated block; antithetic, synthetic normal faults; and drag folds.

The second structural feature is the segmented faults. Small fault zones more commonly consist of isolated segments within a fault array, with fault propagation that is layer/rheology controlled (Lindanger et al. 2007). The fault segments propagate towards each other and form broken-down zone as shown in figure (7b). In other cases, the segments interact, coalesce and give releasing and restraining bends (figure 8a). Childs et al. (1996) 

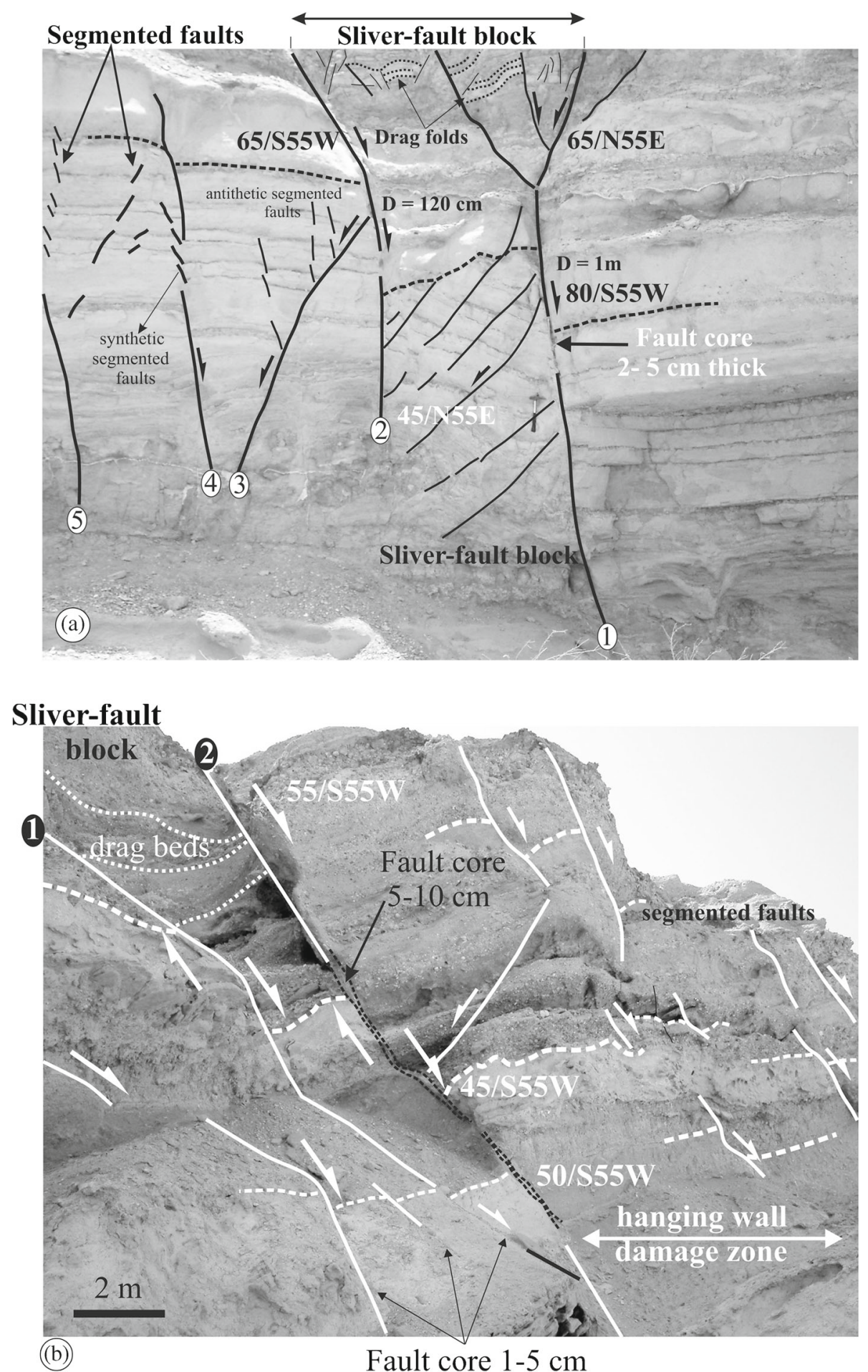

Figure 14. (a) Photograph showing a number of NW small normal faults. The area between faults, no. 1 and 2 , is called sliver fault block. It is characterized by antithetic faults and drag folds. The segmented faults are clear in this vertical section along the faults 3, 4 and 5. The displacement (D) along the faults ranges from 10 to $120 \mathrm{~cm}$. (b) Photograph showing the drag beds in the area between faults 1 and 2, which is called sliver fault block. The displacement along the fault no. 1 is gradually decreasing downward. The hanging wall damage zone along the fault no. 2 is characterized by synthetic small normal faults.

suggested that the segmented fault traces are organized structures, which form at an early stage of fault nucleation and propagation. This type of segmented faults may adhere to the isolated fault model (Walsh and Watterson 1988; Cowie and Scholz 1992; Gillespie et al. 1992; Trudgill and Cartwright 1994; Cartwright et al. 1995; Dawers and Anders 1995; Huggins et al. 1995; Schlische 
et al. 1996; McLeod et al. 2000). This model assumes that the tips of originally isolated faults propagate toward each other until both faults interact and overlap to form a relay zone, which eventually breaches. In other cases, the segmented small normal faults are overlapped and do not interact with each other (figure 14a). The present study suggests that the upward segmentation of the small normal faults is controlled by the rheological differences between sandstone and claystone.

As the segments of the small normal faults link up with increased fault offset, lenses develop in segment linkage areas (Lindanger et al. 2007). The fault lenses may occur before or after full coalescence of the slip planes (figure 17, Bürgmann and Pollard 1994). The formation of fault lenses along the studied faults is related to the initially segmented nature of fault zones. The vertical propagation and branching of the fault segments give lenses, as shown in figure 10(a).

The brittle deformations between the hanging wall and footwall along the fault zones in the area are responsible for the development and growth of clay smearing and fault lenses (figure 16). The clay

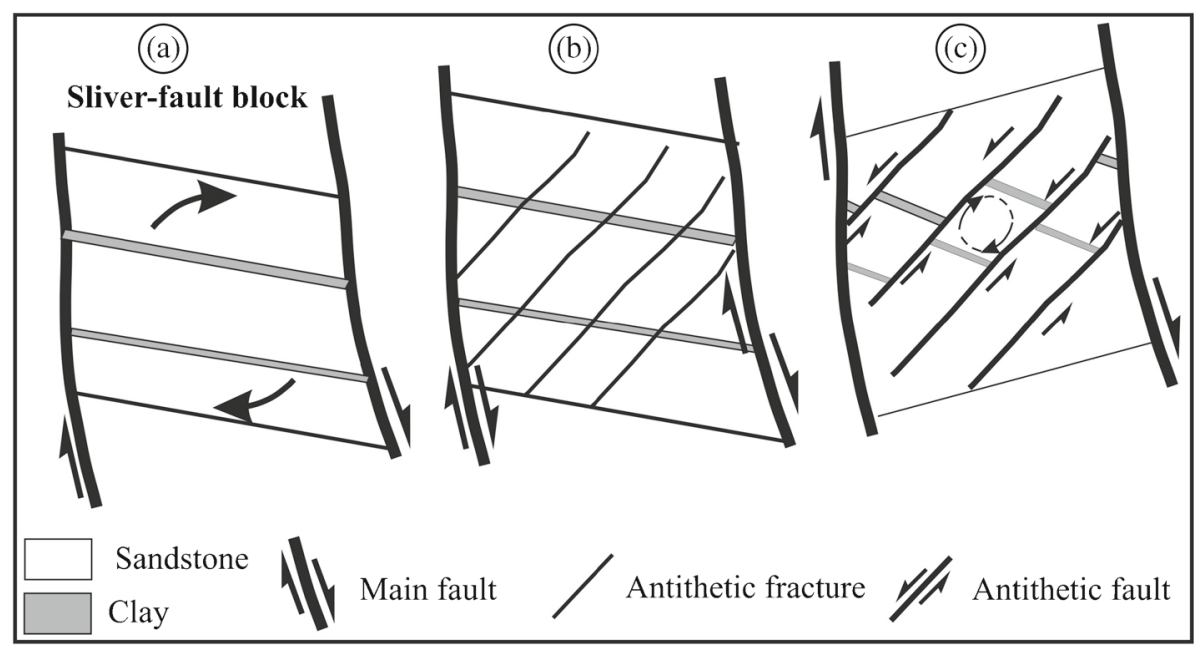

Figure 15. Sketch showing the sliver fault block deformation. (a) Anticlockwise rotation of the fault block between two normal faults. (b) $45^{\circ} / \mathrm{N} 55^{\circ} \mathrm{E}$ antithetic fractures dissect the sliver fault block. (c) Antithetic normal faults with $35^{\circ}$ clockwise rotation of the beds.

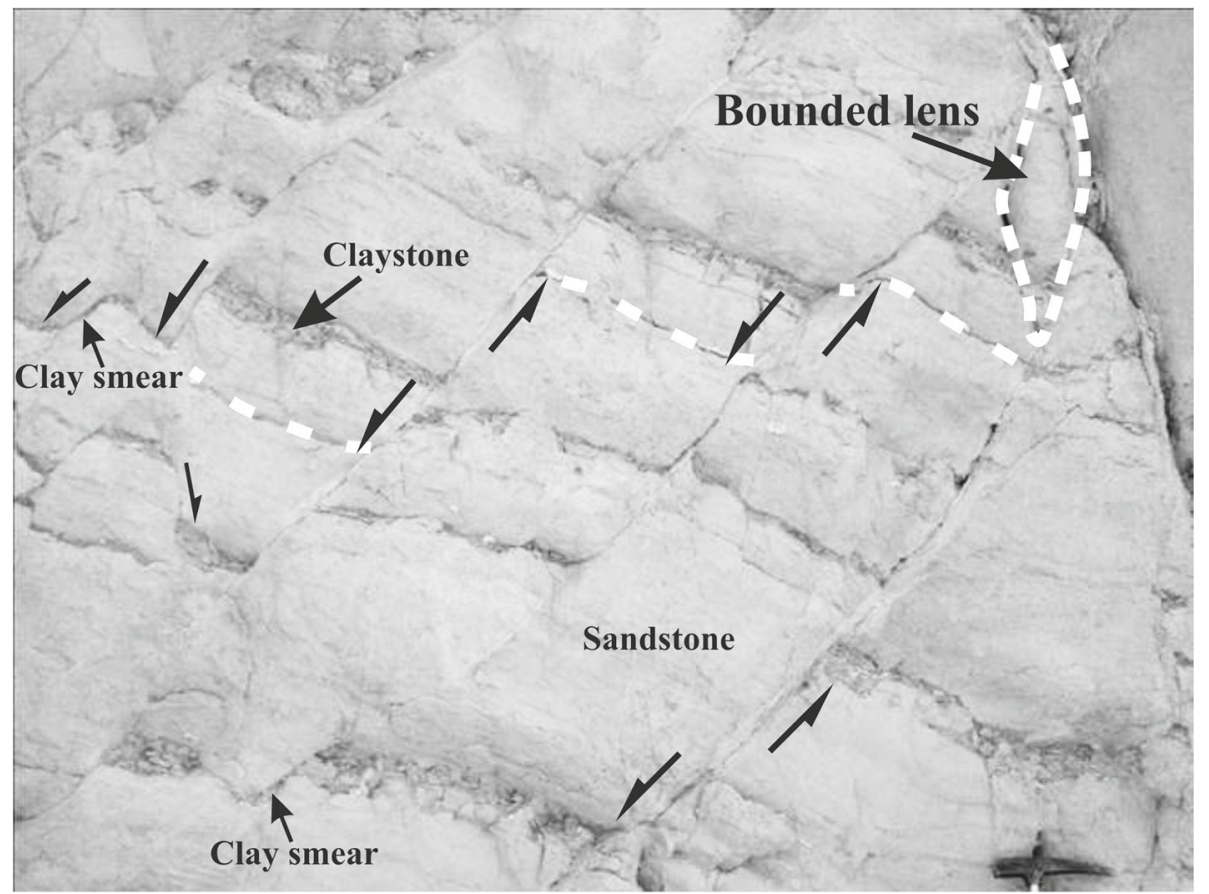

Figure 16. Field photograph showing a number of NE dipping small normal faults. These faults affected the Upper Miocene rocks (interbedded of claystone and sandstone). Fault lens and clay smear are clear along these faults. 


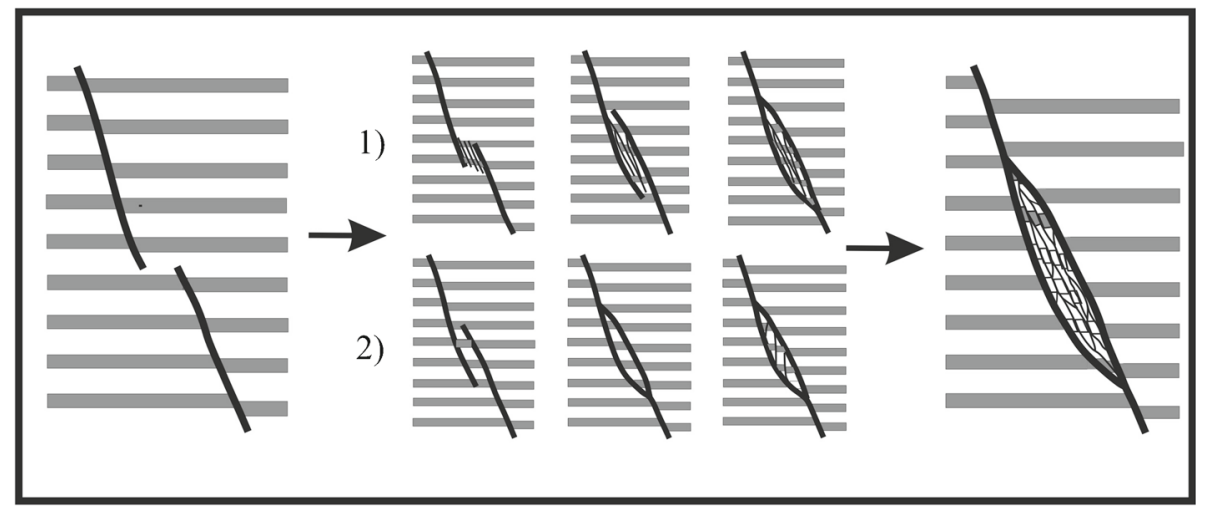

Figure 17. Two scenarios for the development of fault-bounded lens-shaped bodies by coalescence of two non-planar faults. In scenario 1 , the interior of the future lens is deformed before coalescence of the faults. Scenario 2 shows the fault coalescence before major deformation of the interior of the lens (after Van der Zee and Urai 2005).

smears in the fault rocks are probably due to abrasion movement of claystone past sandstones; and shearing deformation between hanging wall and footwall cut-offs of claystone beds. Lindsay et al. (1993) distinguished three types of clay smear: (i) abrasion due to movement past sandstones, (ii) shearing and ductile deformation between hanging wall and footwall cut-offs of shale beds and (iii) injection of clays during fluidization. In the northwestern part of the Red Sea, the clay smears in the small normal fault cores (figures 11 and 16) are in agreement with the first and second types after Lindsay et al. (1993).

\section{Conclusions}

- The trend of the small fault zones in the northwestern Red Sea is mainly NW-SE. The paleostress analysis of these fault zones indicates that the maximum stress axis $(\sigma 1)$ is vertical to subvertical and the minimum stress axis ( $\sigma 3)$ has NE-SW direction.

- The damage zone and the fault core are the main architectural elements of the fault zones. The damage zones are dominated by fractured host rocks and sometimes drag folds, while the fault core zones consist of fault gouge and fault breccia.

- The damage zones across the fault zone are strongly asymmetric. The average ratio between hanging wall and footwall damage zones width is about $3: 1$.

- The fault core zones are generally concentrated in a narrow zone of $\sim 0.5$ to $\sim 8 \mathrm{~cm}$ in width. The faults with displacements of $<1 \mathrm{~m}$ have fault-core widths ranging from 0.5 to $4.0 \mathrm{~cm}$, while the faults with displacements more than $>2 \mathrm{~m}$ have fault-core widths ranging from 4.0 to $8.0 \mathrm{~cm}$.
- A number of structural features were recorded within the fault zones. These features are mechanically related to the growth and linkage of the fault arrays. This indicates that the architecture of the fault zones in the northwestern Red Sea is developed as several tectonic phases.

The first one is a sliver fault block, which accommodates to the movement along the normal faults. The segmented fault is the second feature within the fault zones. The fault segments interact, coalesce and give releasing and restraining bends. The vertical propagation and branching of the fault segments develop fault lenses. The material inside the lens may become more deformed than the surrounding rock. The fault lenses are the third feature recorded in the fault zones. The last feature is clay smears. The clay smears in the fault zones are probably due to abrasion movement of claystone past sandstones, and shearing deformation between hanging wall and footwall cut-offs of claystone beds.

\section{Acknowledgements}

Prof. A Moustafa and Prof. A Shim are thanked for critical reviews of the manuscript. The reviewers are thanked for their useful comments, which greatly improved this manuscript. The author wishes to acknowledge Minia University and Faculty of Science, for funding this work.

\section{References}

Aarland R K and Skjerven J 1998 Fault and fracture characteristics of major fault zone in the northern North Sea: Analyses of 3D seismic and oriented cores in the Brage Field (Block 31/4); In: Structural geology in reservoir characterization (eds) Coward M P, Daltaban T S and Johnson H, Geol. Soc. London, Spec. Publ. 127 209-229. 
Abdel Khalek M L, Abdel Wahed M and Sehim A 1993 Wrenching deformation and tectonic setting of the northwestern part of the Gulf of Aqaba; Geodynamics and sedimentation of the Red Sea-Gulf of Aden rift system; Geol. Surv. Egypt, Spec. Publ. 1 409-445.

Akkad S and Dardir A A 1966 Geology and phosphate deposits of Wasif, Safaga area; Geol. Surv. Egypt 3635.

Angélier J and Mechler P 1977 Sur une méthode graphique de recherche descontraintes principales égalementutilisable en tectoniqueet en seismologie: laméthode des diédresdroits; B. Soc. Géol. Fr. 7(19) 1309-1318.

Antonellini M and Aydin A 1995 Effect of faulting on fluid flow in porous sandstones: Geometry and spatial distribution; AAPG Bull. 79 642-671.

Aydin A and Johnson A M 1978 Development of faults as zones of deformation bands and slip surfaces in sandstone; Pure Appl. Geophys. 116 931-942.

Aydin A and Nur A 1985 The types and role of stepovers in strike-slip tectonics; In: Strike-slip deformation, basin formation and sedimentation (eds) Biddle $\mathrm{K} \mathrm{T}$ and Christie-Blick N; Sot. Econ. Palaeo. Min., Spec. Publ. 37 35-44.

Bastesen E and Braathen A 2010 Extensional faults in fine grained carbonates - analysis of fault core lithology and thickness displacement relationships; J. Struct. Geol. 32 1609-1628.

Beach A, Brown J L, Welbon A L, McCallum J E, Brockbank P and Knott S 1997 Characteristics of fault zones in sandstones from NW England: Application to fault transmissibility; In: Petroleum geology of the Irish Sea and adjacent areas (eds) Meadows N S, Trueblood S P, Hardman M and Cowan G, Geol. Soc. London, Spec. Publ. 124 315-324.

Beach A, Welbon A I, Brockbank P J and McCallum J E 1999 Reservoir damage around faults: Outcrop examples from the Suez rift; Petrol. Geosci. 5 109-116.

Ben-Menahem A, Nur A and Vered M 1976 Tectonics, seismicity and structure of the Afro-Eurasian junction the breaking of an incoherent plate; Phys. Earth Planet. Inter. 12 1-50.

Bense V, Van den Berg E and Van Balen R 2003 Deformation mechanisms and hydraulic properties of fault zones in unconsolidated sediments; The Roer valley rift system, The Netherlands; Hydrogeol. J. 11 319-332.

Bojar A V, Fritz H, Kargl S and Unzog W 2002 Phanerozoic tectonothermal history of the Arabian-Nubian shield in the Eastern Desert of Egypt: Evidence from fission track and paleostress data; J. African Earth Sci. 34 191-202.

Bosworth W and Taviani M 1996 Late Quaternary reorientation of stress field and extension direction in the southern Gulf of Suez, Egypt: Evidence from uplifted coral terraces, mesoscopic fault arrays, and borehole breakouts; Tectonics 15 791-802.

Bosworth W and Strecker M R 1997 Stress field changes in the Afro-Arabian rift system during the Miocene to recent period; In: Structure and dynamic processes in the lithosphere of the Afro-Arabian rift system (eds) Fuchs K, Altherr R, Mueller B and Prodehl C, Tectonophys. 278 47-62.

Bosworth W and McClay K R 2001 Structural and stratigraphic evolution of the Neogene Gulf of Suez, Egypt: a synthesis; In: Peritethyan Rift/Wrench Basin and Passive Margins (eds) Cavazza W, Robertson A H F R and Zeigler $\mathrm{P}$, Memoires due Museum National d' Historie Naturelle de Paris: Peritethys Programme (PTP) and IGCP, Spec. Publ. 369.

Bosworth W, Huchon P and McClay K 2005 The Red Sea and Gulf of Aden basins; J. African Earth Sci. 43 $334-378$.
Bruhn R L, Parry W T, Yonkee W A and Thompson T 1994 Fracturing and hydrothermal alteration in normal fault zones; Pure Appl. Geophys. 142 609-642.

Bürgmann R and Pollard D 1994 Strain accommodation about strike-slip fault discontinuities in granitic rock under brittle-to-ductile conditions; J. Struct. Geol. 16 1655-1674.

Caine J S, Evans J P and Forster C B 1996 Fault zone architecture and permeability structure; Geology $\mathbf{2 4}$ 1025-1028.

Cartwright J A, Trudgill B and Mansfield C S 1995 Fault growth by segment linkage: An explanation for scatter in maximum displacement and trace length data from the Canyonlands Grabens of S. E; Utah; J. Struct. Geol. 17 1319-1326.

Cartwright J A, Mansfield C and Trudgill B 1996 The growth of normal faults by segment linkage; In: Modern developments in structural interpretation, validation and modeling; Geol. Soc. London, Spec. Publ. 99 163177.

Chester F M and Logan J M 1986 Composite planar fabric of gouge from the Punchbowl Fault, California; J. Struct. Geol. 9 621-634.

Chester F M, Evans J P and Biegel R L 1993 Internal structure and weakening mechanisms of the San Andreas Fault; J. Geophys. Res. 98 771-786.

Childs C, Nicol A, Walsh J J and Watterson J 1996 Growth of vertically segmented normal faults; J. Struct. Geol. 18 1389-1397.

Childs C, Walsh J J and Watterson J 1997 Complexity in fault zone structure and implications for fault seal prediction; In: Hydrocarbon seals: Importance for exploration and production (eds) Møller-Pedersen $\mathrm{P}$ and Koestler A G, Norwegian Petroleum Society (NPF), Spec. Publ. 7 61-72.

Clausen J A 2002 The sealing capacity and architecture of shallow faults in sedimentary sequences; PhD thesis, University of Bergen.

Clausen J A and Gabrielsen R H 2002 Parameters that control the development of clay smear at low stress states: An experimental study using ring-shear apparatus; J. Struct. Geol. 24 1569-1586.

Clausen J A, Gabrielsen R H, Johnsen E and Korstgard J A 2003 Fault architecture and clay smear distribution: Examples from field studies and drained ring-shear experiments; Norwegian J. Geol. 83 131-146.

Cochran J R 1983 A model for development of the Red Sea; Am. Assoc. Petr. Geol. B 67 41-69.

Coleman R G 1993 Geologic Evolution of the Red Sea; In: Oxford monographs on geology and geophysics, Oxford University Press, Oxford 24 186p.

Cowie P A and Scholz C H 1992 Physical explanation for the displacement length relationship of faults, using a post-yield fracture mechanics model; J. Struct. Geol. 14 1133-1148.

Crawford B R, Myers R D, Woronow A, Faulkner D R and Rutter E H 2002 Porosity permeability relationships in clay-bearing fault gouge; SPE/ISRM 78214 13p.

Davatzes N C and Hickman S H 2005 Comparison of acoustic and electrical image logs from the Coso geothermal field, CA; In: 30th Stanford University Workshop on Geothermal Reservoir Engineering, 01/31-02/2 2005, SGP-TR-176, 11p.

Dawers N H and Anders M H 1995 Displacement-length scaling and fault linkage; J. Struct. Geol. 17 607-614.

Delvaux D 1993 The TENSOR program for paleostress reconstruction: Examples from the East African and the Baikal rift zones; Terra Nova 5(1) 216.

Delvaux D and Sperner B 2003 Stress tensor inversion from fault kinematic indicators and focal mechanism data: 
the TENSOR program; In: New Insights into Structural Interpretation and Modeling (ed.) Nieuwland D, Geol. Soc. London, Spec. Publ. 212 75-100.

Dixon T H, Stern R J and Hussein I M 1987 Control of Red Sea rift geometry by Precambrian structures; Tectonics $\mathbf{5}$ 551-571.

El Bassyony A A 1982 Stratigraphical studies on Miocene and younger exposures between Quseir and Berenice, Red Sea Coast, Egypt; PhD thesis, Ain Shams University, Cairo.

Forster C B and Evans J P 1991 Hydrogeology of thrust faults and crystalline thrust sheets: Results of combined field and modeling studies; Geophys. Res. Lett. 18 979-982.

Fossen H and Hesthammer J 2000 Possible absence of small faults in the Gullfaks Field, northern North Sea: Implication for downscaling of faults in some porous sandstones; J. Struct. Geol. 22 851-863.

Freund R 1970 Plate tectonics of the Red Sea and Africa; Nature 228453.

Gabrielsen R H and Clausen J A 2001 Horses and duplexes in extensional regimes: A scale-modeling contribution; In: Tectonic models: A volume in honor of Hans Ramberg (eds) Koyi H A and Mancktelow N, Geol. Soc. Am. Memoir 193 219-233.

Gabrielsen R H and Koestler A G 1987 Description and structural implications of fractures in the late Jurassic sandstones of the Troll Field, northern North Sea; Norsk Geologisk Tidsskrift 67 371-381.

Gabrielsen R H, Aarland R K and Alsaker E 1998 Identification and spatial distribution of fractures in porous, siliclastic sediments; In: Structural geology in reservoir characterization (eds) Coward M P, Daltaban T S and Johnson H; Geol. Soc. London, Spec. Publ., pp. 49-64.

Gibbs A D 1983 Balanced cross-section construction from seismic sections in areas of extensional tectonics; J. Struct. Geol. 5 153-160.

Gibbs A D 1984 Structural evolution of extensional margins; J. Geol. Soc. London 141 609-620.

Gillespie P A, Walsh J J and Watterson J 1992 Limitations of dimension and displacement data from single faults and the consequences for data analysis and interpretation; J. Struct. Geol. 14 1157-1172.

Girdler R W and Southren T C 1987 Structure and evolution of the northern Red Sea; Nature 330 716-721.

Heath R, Vanstone S, Swallow J, Ayyad M, Amin M, Huggins P, Swift R, Warburton I, McClay K and Younis A 1999 Renewed exploration in the offshore north Red Sea region, Egypt; In: Proceedings of the 14th Petroleum Conference, Egyptian General Petroleum Corporation, Cairo, Egypt, pp. 16-34.

Heermance R, Shipton Z K and Evans J P 2003 Fault structure control on fault slip and ground motion during the 1999 rupture of the Chelungpu Fault, Taiwan; Bull. Seismol. Soc. Am. 93(3) 1034-1050.

Hempton M 1987 Constraints on Arabian plate motion and extensional history of the Red Sea; Tectonics 6 687-705.

Hermina M, Klitzsch E and List F K 1989 Stratigraphic Lexicon and explanatory notes to the geological map of Egypt, 1:500,000; Conoco Inc, Cairo, Egypt, 263p.

Hesthammer J and Fossen H 1998 The use of diameter data to constrain the structural geology of the Gullfaks Field, northern North Sea; Mar. Petrol. Geol. 15 549-573.

Hesthammer J, Johansen T E S and Watts L 2000 Spatial relationships within fault damage zones in sandstone; Mar. Petrol. Geol. 17 873-893.

Huggins P, Watterson J and Walsh J J 1995 Relay zone geometry and displacement transfer between normal faults recorded in coal-mine plans; J. Struct. Geol. 17(12) 1741-1755.
Joffe S and Garfunkel Z 1987 Plate kinematics of the circum Red Sea: A re-evaluation; Tectonophys. 141 5-22.

Jourde H, Flodin E A, Aydin A, Durlofski L J and Wen X H 2002 Computing permeability of fault zones in Eolian sandstone from outcrop measurements; Am. Assoc. Petr. Geol. B 86 1187-1200.

Khalil S and McClay K R 2002 Extensional fault-related folding, northwestern Red Sea, Egypt: Special Volume; J. Struct. Geol. 24 743-762.

Khalil S and McClay K R 2004 Structural control on Miocene sediment input sites, northwestern Red Sea, Egypt; In: Proceedings of the Seventh Conference of Geology of Sinai for Development, Suez Canal University, Ismailia, pp. 297-315.

Khalil S and McClay K R 2009 Structural control on synrift sedimentation, northwestern Red Sea margin, Egypt; J. Struct. Geol. 26 1018-1034.

Knott S D 1994 Fault zone thickness versus displacement in the Permo-Triassic sandstones of NW England; J. Geol. Soc. London 151 17-25.

Knott S D, Beach A, Brockbank P J, Brown J L, McCallum J E and Welbon A I 1996 Spatial and mechanical controls on normal fault populations; J. Struct. Geol. 18 359-372.

Koestler A G and Ehrmann W U 1991 Description of brittle extensional features in chalk on the crest of a salt ridge (NW Germany); In: The geometry of normal faults (eds) Roberts A M, Yielding G and Freeman B; Geol. Soc. London, Spec. Publ. 56 113-123.

Lehner F K and Pilaar W F 1997 The emplacement of clay smears in synsedimentary normal faults: Inferences from field observations near Frechen, Germany; In: Hydrocarbon seals: Importance for exploration and production (eds) Møller-Pedersen P and Koestler A G, Norwegian Petrol. Soc., Spec. Publ. 7 39-50.

Le Pichon X and Francheteau J 1978 A plate tectonic analysis of the Red Sea-Gulf of Aden area; Tectonophys. 46 369-406.

Lindanger R, Øygaren M, Gabrielsen R H, Mjelde R, Randen T and Tjøstheim B A 2004 Analogue (plaster) modelling and synthetic seismic representation of hangingwall fault blocks above of rampflat ramp faults; First Break 22 22-30.

Lindanger M, Gabrielsen R H and Braathen A 2007 Analysis of rock lenses in extensional faults; Norwegian J. Geol. 87 361-372.

Lindsay N G, Murphy F C, Walsh J J and Watterson J 1993 Outcrop studies of shale smears on fault surfaces; In: The geological modeling of hydrocarbon reservoirs and outcrop analogues (eds) Fint S S and Bryant I D, Blackwell Scientific Publications, Oxford 15 111-123.

Lyberis N 1988 Tectonic evolution of the Gulf of Suez and the Gulf of Aqaba; Tectonophys. 153 209-220.

Mandl G 2000 Faulting in Brittle Rocks: An Introduction to the Mechanics of Tectonic Faults; Springer, Berlin.

Mansfield C S and Cartwright J A 1996 High resolution fault displacement mapping from three-dimensional seismic data: Evidence for dip linkage during fault growth; J. Struct. Geol. 18 249-263.

McCaig A M 1988 Deep fluid circulation in fault zones; Geology 16 867-870.

Mckenzie D P, Davies D and Molnar P 1970 Plate tectonics of the Red Sea and east Africa; Nature 226 243-248.

McLeod A E, Dawers N H and Underhill J R 2000 The propagation and linkage of normal faults: Insights from the Strathspey-Brent-Stratfjord fault array, northern North Sea; Basin Res. 12 263-284.

Mitra G and Ismat Z 2001 Microfracturing associated with reactivated fault zones and shear zones: What can it tell us about deformation history?; In: The nature 
and tectonic significance of fault zone weakening (eds) Holdsworth R E, Strachan R A, Magloughlin J F and Knipe R J; Geol. Soc. London, Spec. Publ. 186 113-140. Montenat C, Ott d'Estevou P, Jarriage J J and Richert J P 1998 Tectonic and sedimentary evolution of the Gulf of Suez and the northwestern Red Sea; Tectonophys. 153 161-177.

Morgan P 1990 Egypt in the tectonic framework of global tectonics; In: The geology of Egypt (ed.) Said R, Balkema, Rotterdam, pp. 91-111.

Morley C K, Nelson R A, Patton T L and Munn S G 1990 Transfer zones in the east African rift system and their relevance to hydrocarbon exploration in rifts; Bull. Am. Assoc. Petrol. Geol. 74 1234-1253.

Moustafa A R 1997 Controls on the development and evolution of transfer zones: The influence of basement structure and sedimentary thickness in the Suez rift and Red Sea; J. Struct. Geol. 19 755-768.

Nelson E P, Kullman A J and Gardner M H 1999 Fault-fracture networks and related fluid flow and sealing, Brushy Canyon Formation, West Texas; In: Faults and subsurface fluid flow in the shallow crust (eds) Goodwin L B, Mozley P S, Moore J M and Haneberg W C, Geophysical Monograph 113, American Geophysical Union, Washington, pp. 69-81.

Orszag-Sperber F, Purser B H, Rioual M and Plaziat J C 1998 Post Miocene sedimentation and rift dynamics in the southern Gulf of Suez and northern Red Sea; In: Sedimentation and tectonics of rift basins: Red Sea-Gulf of Aden (eds) Purser B H and Bosence D W J, Chapman and Hall, London, pp. 427-447.

Ouenes A 2000 Practical application of fuzzy logic and neural networks to fractured reservoir characterization; Comput. Geosci. 26 953-962.

Peacock D C P and Zhang X 1993 Field examples and numerical modelling of oversteps and bends along normal faults in cross-section; Tectonophys. 234 147167.

Peacock D C P and Sanderson D J 1994 Geometry and development of relay ramps in normal fault systems; $A A P G$ Bull. 78 147-165.

Philobbos E R and El-Hadded A A 1983 Contribution to the lithostratigraphy of Miocene and Pliocene sediments of the Red Sea coastal zone (abstract); Geol. Soc. Egypt.

Purser B H and Bosence D W J (eds) 1998 Sedimentation and tectonics of rift basins: Red Sea-Gulf of Aden; Chapman and Hall, London, 663p.

Quennell A M 1984 The western Arabian rift system; In: The geological evolution of the eastern Mediterranean (eds) Dixon J E and Robertson A H F, Blackwell Scientific, Oxford, pp. 775-788.

Said R (ed.) 1990 The geology of Egypt; Balkema, Rotterdam, 734p.

Schlische R W, Young S S, Ackermann R V and Gupta A 1996 Geometry and scaling relations of a population of very small rift-related normal faults; Geology 24 683-686.

Shipton Z K and Cowie P A 2001 Damage zone and slipsurface evolution over $\mathrm{mm}$ to $\mathrm{km}$ scales in high-porosity Navajo sandstone, Utah; J. Struct. Geol. 23 1825-1844.
Sibson R H 1977 Fault rocks and fault mechanisms; J. Geol. Soc. London 133 191-213.

Sibson R H 1992 Implications of fault-valve behavior for rupture nucleation and recurrence; Tectonophys. $211283-$ 293.

Sibson R H 1994 Crustal stress, faulting and fluid flow; In: Geofluids: Origin migration and evolution of fluids in sedimentary basin; Geol. Soc. London, Spec. Publ. 78 69-84.

Sibson R H 1996 Structural permeability on fluid-driven fault-fracture meshes; J. Struct. Geol. 18 1031-1042.

Sibson R H and Scott J 1998 Stress/fault controls on the containment and release of overpressured fluids: Examples from gold-quartz vein systems in Juneau, Alaska; Victoria, Australia and Otago, New Zealand; Ore Geol. Rev. 13 293-306.

Smith L, Forster C and Evans J 1990 Interaction of fault zones, fluid flow, and heat transfer at the basin scale; In: Hydrogeology of low permeability environments (eds) Stein S and Wysession M; Selected Papers in Hydrogeology 2, International Association for Hydrogeologists, pp. $41-67$.

Sperrevik S, Færseth R and Gabrielsen R 2000 Experiments on clay smear formation along faults; Petrol. Geosci. 6 $113-123$.

Steckler M S, Berthelot F, Lyberis N and Le Pichon X 1988 Subsidence in the Gulf of Suez: Implications for rifting and plate kinematics; Tectonophys. 153 249270.

Stewart I S and Hancock P L 1991 Scales of structural heterogeneity with neotectonic normal fault zones in the Aegean region; J. Struct. Geol. 13 191-204.

Tewfik N and Ayyad M 1982 Petroleum exploration in the Red Sea Shelf of Egypt; Sixth Exploration Seminar; Egyptian General Petroleum Corporation, Cairo.

Trudgill B and Cartwright J 1994 Relay-ramp forms and normal-fault linkages, Canyonlands National Park, Utah; Geol. Soc. Am. Bull. 106 1143-1157.

Van der Zee W and Urai J L 2005 Processes of normal fault evolution in a siliciclastic sequence: A case study from Miri, Sarawak, Malaysia; J. Struct. Geol. 10 239-247.

Walsh J J and Watterson J 1988 Analysis of the relationship between displacements and dimensions of faults; J. Struct. Geol. 10 239-247.

Willemse E J M and Pollard D D 2000 Normal fault growth: Evolution of tipline shapes and slip distribution; In: Aspects of tectonic faulting (eds) Lehner F K and Urai J L, Springer, Berlin, pp. 191-226.

Wu S and Groshong R H 1991 Low-temperature deformation of sandstone, southern Appalachian fold-thrust belt; Geol. Soc. Am. Bull. 103 861-875.

Younes A I, Engelder T E and Bosworth W 1998 Fracture distribution in faulted basement blocks, Gulf of Suez Egypt; In: Structural geology and reservoir characterization (eds) Coward M P, Daltaban T S and Johnson H, Geol. Soc. London, Spec. Publ. 127 167-190.

Younes A I and McClay K R 2001 Role of basement fabric on rift architecture: Gulf of Suez-Red Sea, Egypt; $A m$. Assoc. Petr. Geol. B. 86 1003-1102. 